\title{
Regulation of male sex determination: genital ridge formation and $S r y$ activation in mice
}

\author{
Satomi S. Tanaka $\cdot$ Ryuichi Nishinakamura
}

Received: 24 April 2014/Revised: 8 August 2014/Accepted: 11 August 2014/Published online: 20 August 2014

(C) The Author(s) 2014. This article is published with open access at Springerlink.com

\begin{abstract}
Sex determination is essential for the sexual reproduction to generate the next generation by the formation of functional male or female gametes. In mammals, primary sex determination is commenced by the presence or absence of the $\mathrm{Y}$ chromosome, which controls the fate of the gonadal primordium. The somatic precursor of gonads, the genital ridge is formed at the mid-gestation stage and gives rise to one of two organs, a testis or an ovary. The fate of the genital ridge, which is governed by the differentiation of somatic cells into Sertoli cells in the testes or granulosa cells in the ovaries, further determines the sex of an individual and their germ cells. Mutation studies in human patients with disorders of sex development and mouse models have revealed factors that are involved in mammalian sex determination. In most of mammals, a single genetic trigger, the Y-linked gene Sry (sex determination region on $\mathrm{Y}$ chromosome), regulates testicular differentiation. Despite identification of Sry in 1990, precise mechanisms underlying the sex determination of bipotential genital ridges are still largely unknown. Here, we review the recent progress that has provided new insights into the mechanisms underlying genital ridge formation as well as the regulation of Sry expression and its functions in male sex determination of mice.
\end{abstract}

Keywords Six 1 - Six 4 - Sox 9 - Transcriptional network · $\mathrm{Nr} 5 \mathrm{a} 1 / \mathrm{Ad} 4 \mathrm{BP} / \mathrm{Sf} 1$

S. S. Tanaka $(\bowtie) \cdot R$. Nishinakamura

Department of Kidney Development, Institute of Molecular

Embryology and Genetics, Kumamoto University, 2-2-1 Honjo,

Kumamoto 860-0811, Japan

e-mail: stanaka@kumamoto-u.ac.jp

R. Nishinakamura

e-mail: ryuichi@kumamoto-u.ac.jp

\begin{tabular}{|c|c|}
\hline Abbreviations & \\
\hline Alp1/Akp2/TNAP & $\begin{array}{l}\text { Alkaline phosphatase, liver/bone/ } \\
\text { kidney }\end{array}$ \\
\hline AR & Androgen receptor \\
\hline Arx & $\begin{array}{l}\text { X-linked aristaless-related } \\
\text { homeobox }\end{array}$ \\
\hline ATR-X & $\begin{array}{l}\text { Alpha thalassemia, mental } \\
\text { retardation, X-linked }\end{array}$ \\
\hline Cbln4 & Cerebellin precursor 4 \\
\hline $\mathrm{Cbx} 2 / \mathrm{M} 33$ & $\begin{array}{l}\text { Chromobox homolog } 2 / \text { mouse } \\
\text { polycomb group member M33 }\end{array}$ \\
\hline ChIP & Chromatin immunoprecipitation \\
\hline Col9a3 & Collagen, type IX, alpha 3 \\
\hline Cyp17a1 & $\begin{array}{l}\text { Cytochrome P450, family } 17 \text {, } \\
\text { subfamily a, polypeptide } 1\end{array}$ \\
\hline Cyp26b1 & $\begin{array}{l}\text { Cytochrome P450, family } 26 \text {, } \\
\text { subfamily b, polypeptide } 1\end{array}$ \\
\hline Dax1/Nr0b1 & $\begin{array}{l}\text { Dosage-sensitive sex reversal, } \\
\text { adrenal hypoplasia critical region, } \\
\text { on chromosome X, gene } 1 / \text { nuclear } \\
\text { receptor subfamily } 0 \text { group B, } \\
\text { member } 1\end{array}$ \\
\hline dazl & Deleted in azoospermia-like \\
\hline Dhh/Ptch1 & Desert hedgehog/patched 1 \\
\hline Dmrt1 & $\begin{array}{l}\text { Doublesex and mab-3 related } \\
\text { transcription factor } 1\end{array}$ \\
\hline DSD & Disorders of sex development \\
\hline E & Embryonic day \\
\hline EG cells & Embryonic germ cells \\
\hline EGF & Epidermal growth factor \\
\hline Eif2s3y & $\begin{array}{l}\text { Eukaryotic translation initiation } \\
\text { factor } 2 \text {, subunit } 3 \text {, structural gene } \\
\text { Y-linked }\end{array}$ \\
\hline EMT & Epithelial mesenchymal transition \\
\hline Emx2 & Empty spiracles homeobox 2 \\
\hline
\end{tabular}




\begin{tabular}{|c|c|c|}
\hline FGF9 & Fibroblast growth factor 9 & PGCs \\
\hline FGFR2 & Fibroblast growth factor receptor 2 & PGCLCs \\
\hline ESCs & Embryonic stem cells & Prdm1/Blimp1 \\
\hline Esr & Estrogen receptor & \\
\hline Fog2/Zfpm2 & $\begin{array}{l}\text { Friend of GATA-2/zinc finger } \\
\text { protein, multitype } 2\end{array}$ & Ptgds \\
\hline Fox12 & Forkhead box L2 & Ptgdr \\
\hline Gadd45g & $\begin{array}{l}\text { Growth arrest and DNA damage- } \\
\text { inducible } 45 \text { gamma }\end{array}$ & $\begin{array}{l}\text { RA } \\
\text { Rspo1 }\end{array}$ \\
\hline Gata4 & GATA binding protein 4 & \\
\hline HMG & High mobility group & Six 1,4 \\
\hline $3 \beta-\mathrm{Hsd}$ & $\begin{array}{l}3 \text { Beta-hydroxysteroid } \\
\text { dehydrogenase }\end{array}$ & $\begin{array}{l}\text { Sox } 3,8,9,10 \\
\text { SP1 }\end{array}$ \\
\hline ieSCs & Induced embryonic Sertoli-like cells & Sry \\
\hline Ifitm3/mil-1/fragilis & $\begin{array}{l}\text { Interferon induced transmembrane } \\
\text { protein } 3 \text { /mouse Ifitm-like protein- } \\
1 \text { /fragilis }\end{array}$ & Tes \\
\hline IGF & Insulin-like growth factor & TGF- $\beta$ \\
\hline Jmjd1a/Tsga/ & Jumonji domain-containing protein & Wnt4 \\
\hline Jhdm2a/Kdm3a & $\begin{array}{l}\text { 1A/testis-specific gene } \mathrm{A} / \mathrm{jmjC} \\
\text { domain-containing histone } \\
\text { demethylation protein } 2 \mathrm{~A} / \mathrm{lysine} \\
(\mathrm{K}) \text {-specific demethylase } 3 \mathrm{~A}\end{array}$ & $\begin{array}{l}\text { Wt1 } \\
\text { Wt1+KTS }\end{array}$ \\
\hline iPS & Inducible pluripotent cells & Wt1-KTS \\
\hline lacZ & Beta-D-galactosidase & \\
\hline Lhx9 & LIM homeobox 9 & \\
\hline MAP3K4/MEKK4 & Mitogen-activated protein kinase & \\
\hline
\end{tabular}

MAPK

MEFs

Mfge8

MKK4

MIS/Amh

$\mathrm{mvh} / \mathrm{Ddx} 4$

Nr5a1/Ad4BP/Sf1 Nuclear receptor subfamily 5, group

$\mathrm{Ntf3}$

oct-3/oct-4/Pou5f1

PdgfA

Pdgfra

Pod1/Tcf21/

bHLHa23/

capsulin/epicardin A, member 1/adrenal 4 bindingprotein/steroidogenic factor 1

Mitogen-activated protein kinase

Mouse embryonic fibroblasts

Milk fat globule-EGF factor 8

Mitogen-activated protein kinase kinase 4

Müllerian inhibitory substance/antiMüllerian hormone

Mouse vasa homolog/DEAD box polypeptide 4

Neurotrophin 3

Octamer-binding transcription

factor 3/octamer-binding

transcription factor 4/POU domain,

class 5 , transcription factor 1

Platelet-derived growth factor

subunit A

Platelet-derived growth factor

receptor alpha

Podocyte-expressed 1/transcription

factor 21/class A basic helix-loop-

helix protein 23/capsulin/epicardin kinase kinase 4
Primordial germ cells

PGC-like cells

PR domain-containing 1, with ZNF

domain/B-lymphocyte-induced

maturation protein 1

Prostaglandin D2 synthase

Prostaglandin D2 receptor

Retinoic acid

Roof plate-specific Spondin 1 (Rspondin 1)

Sine oculis-related homeobox 1, 4

Sry-related HMG box 2, 8, 9, 10

Specificity protein 1

Sex determination region on $\mathrm{Y}$

chromosome

Testis-specific enhancer region of Sox9

Transforming growth factor- $\beta$

Wingless-type MMTV integration

Wilms' tumor 1

Isoform of Wt1 containing an additional three amino acids (lysine, threonine, and serine)

Isoform of Wt1 not containing an additional three amino acids (lysine, threonine, and serine)

\section{Introduction}

The genital ridge is the somatic precursor of gonads in both sexes. This is a unique primordium in organ formation because of its bipotential nature. A single primordium gives rise to one of two organs, a testis or an ovary. The formation of genital ridges begin on the ventral surface of the mesonephros as paired thickenings of the epithelial layer at around embryonic day (E) 9.5 in mouse embryos (Fig. 1). This occurrence is accompanied by proliferation of the coelomic epithelium that gives rise to the somatic lineage precursors of the gonad. When the coelomic epithelium proliferates, the underlying basement membrane becomes fragmented to facilitate the migration of coelomic epithelial cells into the dorsal inner mesenchyme region through the basement membrane layer to form genital ridges (Fig. 1).

The genital ridge is composed of somatic cell lineages and germ cells. However, these two lineages are formed at different developmental stages and positions in the embryo. Progenitor cell formation of germ cells begins with activation of PR domain zinc finger protein (Prdm) 1 (also known as Blimpl) in a subset of epiblast cells in the proximal region of the pre-gastrulation mouse embryo at around E6.25. Progenitor cells form a cellular cluster and express Prdml along with interferon-induced 
transmembrane protein (Ifitm) 3 (also known as mil-1/fragilis) at the posterior end of the streak stage embryo at around E6.75. At E7.25, primordial germ cells (PGCs) are specified in the progenitor cell cluster and then translocate from the mesoderm to the endoderm. Thereafter, PGCs are incorporated into the hindgut invagination and then distributed along the length of the embryonic gut. PGCs further migrate through the dorsal mesentery and settle into the genital ridge at around E10.0 [1-11]. After PGC colonization, the decision occurs for the bipotential gonad to develop as either a testis or an ovary. The fate of the gonad is determined by differentiation of somatic cells into Sertoli cells or granulosa cells. Sertoli cells in XY gonads and granulosa cells in XX gonads are the supporting cells that interact with and nurture the germ cells. Therefore, sex determination is essential for sexual reproduction to produce the next generation by the formation of functional male or female gametes. Furthermore, gonadal somatic cells play crucial roles in germ cell development in the gonads of both sexes through their cellular interactions, but the precise mechanisms are unclear.

There are widely diverse systems of sex determination in the animal kingdom. In mammalian sex determination, expression of the Y-linked gene Sry (sex determination region on $\mathrm{Y}$ chromosome) shifts the bipotential embryonic gonad toward a testicular fate [12-14]. This Sry system appears to be unique to mammals, although the absence of Sry has been reported in some species of eutherian mammals [15]. The primary function of Sry is to induce differentiation of pre-Sertoli cells, which is essential for testis differentiation of the bipotential gonad. The fate of the embryonic gonad further determines the sex of an individual and the germ cells. In testes, germ cells differentiate into sperms, whereas in ovaries, germ cells differentiate into oocytes. These male and female gametes combine and generate the next generation by mixing their genetic information.

Therefore, formation of the genital ridge, sex determination of bipotential gonads, and subsequent testicular or ovarian differentiation are critical steps not only to establish sex of an individual, but also to generate the next generation by the formation of functional male or female gametes.

In human patients, disorders of sex development (DSD) are congenital conditions characterized by atypical development of chromosomal, gonadal, or anatomical sex (for a review $[16,17])$. It is estimated that up to $2 \%$ of all live births have DSD [18]. Mutation studies in human patients with DSD and mouse models have revealed factors that are involved in sex development. Most of the factors influencing sex determination are transcriptional regulators, whereas factors influencing sex differentiation are frequently related to hormonal signaling. In particular, mouse models employing targeted mutagenesis and transgenesis have contributed greatly to our understanding of gene functions and the transcriptional/signaling networks in sex development (for reviews [19-26]). Thus far, molecular mechanisms underlying genital ridge formation and Sry activation in male sex determination are poorly understood, unlike the subsequent testicular or ovarian differentiation. However, recent studies in mouse models have provided new insights into these critical steps. In this review, we mainly focus on the early stages of genital ridge formation and Sry activation during male sex determination in mice.

\section{Formation of the genital ridge}

Overview of genital ridge formation and development

The formation of genital ridges begins on the ventral surface of the mesonephros as paired thickenings of the epithelial layer, which is accompanied by proliferation of the coelomic epithelium at around E9.5 in mouse embryos (Fig. 1). Cell fate mapping analyses revealed that coelomic epithelial cells give rise to somatic lineages of the bipotential gonad. Some coelomic epithelial cells proliferate, undergo epithelial-to-mesenchymal transition (EMT), and migrate into the dorsal inner mesenchyme region to form genital ridges [27-29]. Mutant mouse analyses have shown that several factors, especially some key transcription factors, are involved in the formation and development of genital ridges. The key genes involved in genital ridge formation are outlined in "Box 1".

Impaired gonadal formation in most mutant mouse embryos is associated with downregulation or ectopic upregulation of the orphan nuclear receptor $\mathrm{Nr} 5 \mathrm{al}$ (also known as $A d 4 B P / S f 1)$. Embryos lacking the LIM homeobox protein $\operatorname{Lh} x 9\left(\operatorname{Lh} x 9^{-/-}\right)$exhibit impaired gonad formation accompanied by a significant reduction of $\mathrm{Nr} 5 \mathrm{al}$ expression [30]. Embryos lacking the zinc finger transcription factor Wt1 fail to develop kidneys and gonads [31]. An isoform of Wt1 lacking an additional three amino acids (lysine, threonine, and serine) (Wt1-KTS) is also essential for the formation and development of the bipotential gonad [32]. Wt1-KTS binds to the Nr5al promoter and activates its expression in cooperation with Lhx9 [33]. In embryos with conditional inactivation of the GATA zinc finger transcription factor Gata4 after E8.75, impaired genital ridge formation is corroborated by the absence of $\operatorname{Lh} x 9$ and $N r 5 a 1$ expression [34]. Embryos lacking the chromatin modification and remodeling factor $C b x 2$ (also known as M33) $\left(C b x 2^{-/-}\right)$show gonadal growth defects accompanied by reduced expression of Lhx9, Nr5al, and Gata4 [35, 36]. Furthermore, chromatin immunoprecipitation (ChIP) assays using adrenocortical $\mathrm{Y}-1$ cells show direct binding of $\mathrm{Cdx} 2$ 
to the Nr5al locus [37]. Embryos lacking the insulin/insulin-like growth factor (IGF) signaling pathway show impaired gonadal development accompanied by a decrease in $N r 5 a 1$ expression $[38,39]$. Embryos lacking the basic helix-loop-helix transcription factor Podl (Podl lacZ/lacZ) are markedly hypoplastic in both $\mathrm{XX}$ and $\mathrm{XY}$ gonads, which is accompanied by ectopic expansion of the Nr5a1 expression domain in the gonads and mesonephroi [40]. Biochemical approaches further demonstrate that Pod1 transcriptionally represses $\mathrm{Nr} 5 \mathrm{al}$ expression [40, 41].

We also found that homeodomain proteins Six1 and Six 4 regulate $\mathrm{Nr} 5 \mathrm{al}$ expression in genital ridge formation [42]. Sixl and Six4 genes belong to the mammalian homolog of the Drosophila sine oculis homeobox (Six) family, which includes six member genes (Sixl to Six 6 ) in the mouse genome. Six 1 and Six 4 have redundant functions in mouse embryonic development, possibly through transactivation of common target genes, because Six 1 and Six4 bind to a common binding site (MEF3 site) for transactivation (for reviews [43, 44]). Sixl and Six4 dou-

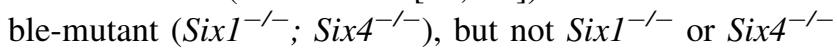
single-mutant mouse embryos, have smaller gonads and adrenal glands than those of their control counterparts [42, 45]. This abnormality is accompanied by a significant reduction in the expression of Nr5al, but not Gata4 or other genes involved in gonadal formation. Reporter and ChIP assays have further shown that Six 1 and Six 4 transactivate $\mathrm{Nr} 5 \mathrm{al}$ expression through the MEF3 site at the $5^{\prime}$ flanking region of $\mathrm{Nr} 5 \mathrm{al}$ in the M15 mouse mesonephric cell line [42].

In addition, the EMT and subsequent ingression of gonadal progenitor cells are critical steps for genital ridge formation, but precise mechanisms underlying the regulation of EMT remain unclear. The paired-like homeobox protein Emx2 has been implicated in the maintenance of epithelial polarity and the EMT and subsequent ingression of gonadal progenitor cells, possibly through the suppression of EGF receptor (Egfr) expression [28]. Although

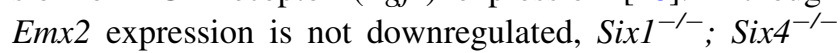
genital ridges show delayed/reduced EMT and subsequent ingression of gonadal progenitor cells [42]. Ectopic expression of human SIXI in the mammary gland epithelium of adult mice has been reported to induce tumors. SIX1 misexpression facilitates expansion of the mammary epithelial stem/progenitor cell pool and induces mammary tumors that undergo EMT [46]. These observations suggest that Six 1 and Six 4 are also implicated in regulation of the EMT and subsequent ingression of gonadal progenitor cells.

Collectively, these findings indicate that Nr5a1 is a critical factor for the formation and development of gonadal precursor cells (Fig. 1). At the initial stage of genital ridge formation, Gata4, Six 1, and Six 4 contribute to the formation of $\mathrm{Nr} 5 \mathrm{al}$-positive gonadal progenitor cells in the coelomic epithelium. Lhx9, Wt1-KTS, and insulin/ IGF signaling activity are also required for $\mathrm{Nr} 5 \mathrm{al}$ expression and promotion of gonadal progenitor cell proliferation in bipotential genital ridges. In addition, Emx2 and possibly Six 1 and Six 4 contribute to the regulation of EMT and subsequent ingression of progenitor cells (Fig. 1). After the ingression, $\mathrm{Cbx} 2$ and probably Pod 1 contribute to $\mathrm{Nr} 5 \mathrm{al}$ expression and progenitor cell growth and/or differentiation in the bipotential gonad.

Potential functions of Nr5a1 in genital ridge formation

It has been proposed that Nr5a1 acts dose dependently. Nr5a1-positive progenitor cells in the coelomic epithelium give rise to the somatic lineages of gonads and adrenal glands. In $\mathrm{Nr}_{5} \mathrm{al}^{+/-}$mouse embryos, their adrenal glands are underdeveloped and show reduced cellular proliferation [47]. Compound mutant studies in $\mathrm{Sixl}^{+/-}, \mathrm{Six}^{+/-}$, and $\mathrm{NrSal}^{+/-}$embryos also demonstrate impaired formation of gonadal progenitor cells, which is dependent on the $\mathrm{Nr} 5 \mathrm{al}$ expression level [42]. Embryos with homozygous deletion of $\mathrm{Nr} 5 \mathrm{al}\left(\mathrm{Nr}^{2} \mathrm{al}^{-/-}\right)$exhibit regression of the gonads by E12.5 with apoptosis of gonadal somatic cells [48-50]. In contrast, ectopic expansion of the Nr5a1 expression domain in Podl lacZlacZ gonads is accompanied by an increase in the number of fetal Leydig cells [40]. In addition, $\mathrm{Nr} 5 \mathrm{al}$ overexpression in $\mathrm{Nr} 5 \mathrm{al}^{-/-}$mice rescues the impaired gonad and spleen development, but not the impaired adrenal gland development. This difference in rescue effects might be dependent in part on the differential levels of $\mathrm{Nr} 5 \mathrm{al}$ expression among tissues and differential sensitivities to the gene dosage [51].

Nr5a1 plays critical roles in the activation of a set of genes involved in steroidogenesis, such as Cyp17al and $3 \beta$-Hsd in Leydig cells. Indeed, Nr5al was first identified as a gene encoding a common transactivating factor of steroidogenic genes [52-54]. Nr5a1 also plays important roles in a variety of physiological activities (for reviews $[55,56])$. It could be postulated that Nr5a1 modulates the expression of target gene sets that are implicated in various physiological activities, including metabolism and stimulation of cell proliferation, differentiation, and survival, which are essential for gonadal development. This hypothesis is supported by the impaired gonad and adrenal gland formation in embryos lacking the insulin/IGF signaling pathway. The insulin/IGF signaling pathway is known to modulate a variety of physiological activities (for a review [57]). Mouse embryos lacking the insulin/IGF signaling pathway show reduced proliferation of gonadal and adrenal progenitor cells, which is accompanied by downregulation of hundreds of genes including Nr5al [39]. Thus, reduced Nr5a1 activity might impair the 
a
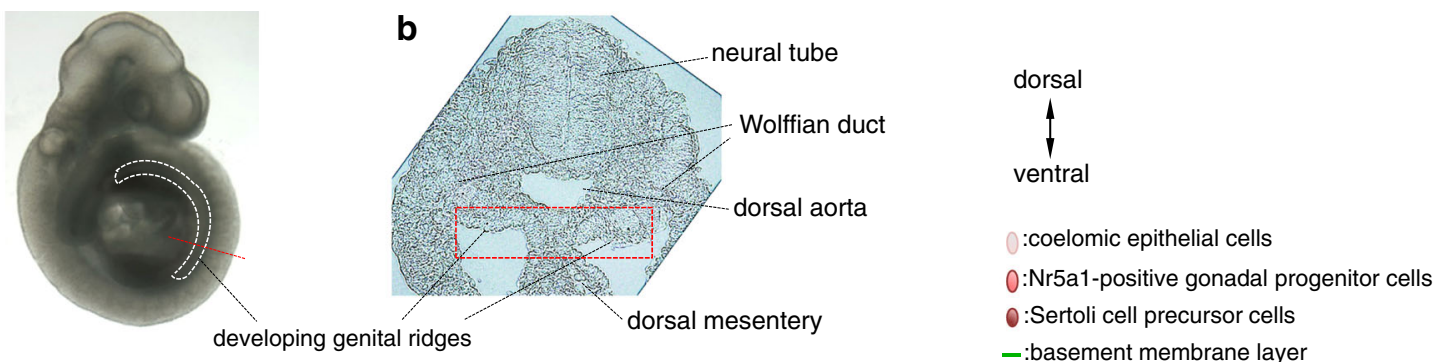

C

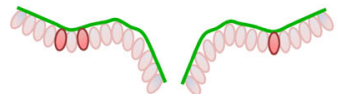

E9.5

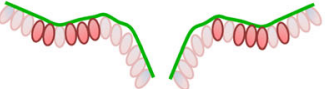

E10.0

(tail somite 0 stage)

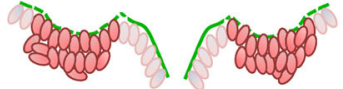

E10.5

(tail somite 6 stage)

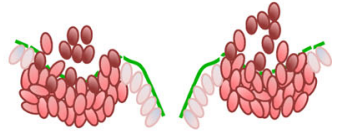

E10.75

(tail somite 9 stage)

d
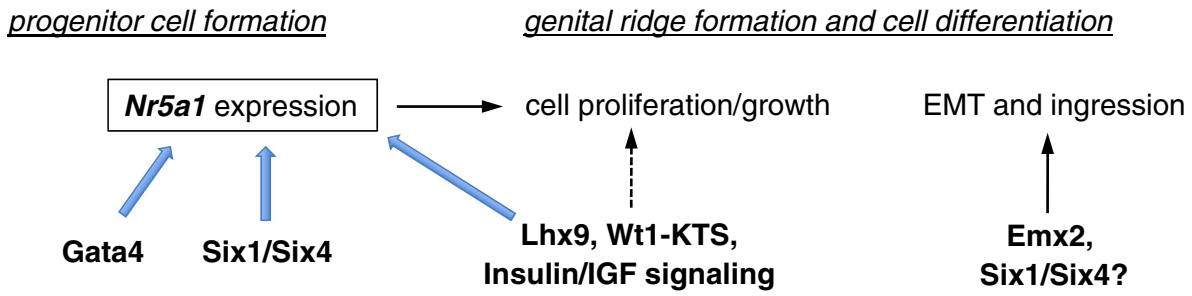

Fig. 1 Formation of genital ridges. In mouse embryos, genital ridges are formed on the ventral surface of the mesonephros as paired thickenings of the epithelial layer, which is accompanied by proliferation of the coelomic epithelium from the anterior portion. a Embryonic day (E) 10 mouse embryo. White dashed line indicates the location of developing genital ridges. Red dashed line indicates the position of the section in (b). b Transverse section of developing genital ridges, representing the dorsal to the top and the ventral to the bottom. c Schematic illustrations of genital ridge formation. The rectangle in b outlines the approximate position in c. Some Nr5a1 (also known as Ad4BP/Sf1)-positive gonadal progenitor cells are formed in the E9.5 coelomic epithelium. The number of Nr5a1positive cells increases at E10.0 (around the 0 tail somite stage), and multilayered Nr5a1-positive cells are expanded at E10.5 (around the 6-tail somite stage) in the coelomic epithelium. Thereafter, Nr5a1positive progenitor cells migrate into the dorsal inner mesenchyme

physiological activities of the progenitor cells, resulting in impaired gonad and adrenal gland formation.

At the later stage, Nr5a1 regulates the expression of key genes that are crucial for testicular differentiation in $\mathrm{XY}$ gonad development, such as Sry-related HMG box 9 (Sox 9$)$ and Müllerian inhibitory substance $[M I S$, also known as anti-Müllerian hormone $(\mathrm{Amh})]$ [58, 59].

Initiation of genital ridge formation and $\mathrm{Nr} 5 \mathrm{al}$ upregulation

A subpopulation of coelomic epithelial cells that express Gata4 and Nr5al are thought to be the initial population that gives rise to the somatic lineages of the genital ridge. region through the basement membrane layer to form the genital ridge primordium (E11.75, around the 9-tail somite stage). In XY gonads, a proportion of Nr5a1-positive daughter cells derived from the coelomic epithelium express Sry to become Sertoli cell precursors. d Scheme for the molecular network that regulates formation and development of Nr5a1-positive gonadal progenitor cells. Genital ridge formation begins from the anterior part of the coelomic epithelium, which is accompanied by Gata4 and subsequent $\mathrm{Nr} 5 \mathrm{al}$ expression. Six 1 and Six 4 directly transactivate $\mathrm{Nr} 5 \mathrm{al}$ in gonadal progenitor cells of the coelomic epithelium. Lhx9, Wt1-KTS, and insulin/insulin-like growth factor (IGF) signaling activity are required to promote gonadal progenitor cell proliferation and form the bipotential genital ridges, which are accompanied by Nr5al upregulation. Emx 2 and possibly Six 1 and Six 4 contribute to regulation of the epithelial-to-mesenchymal transition (EMT) and subsequent ingression of the progenitor cells

Thus far, the upstream regulator(s) of Gata4 in genital ridge formation are unknown. In contrast, as described above, several upstream regulators of $\mathrm{Nr} 5 \mathrm{al}$ have been reported by analyses of mutant mouse embryos ("Box 1"). Nr5al expression is regulated through several lineagespecific enhancers such as the fetal Leydig cell-specific enhancer in the embryonic gonad [60]. Therefore, combinations of upstream regulatory factors may facilitate the initiation and maintenance of $\mathrm{Nr} 5 \mathrm{al}$ expression in gonadal progenitors and specific lineages in developing gonads. At the onset of $\mathrm{Nr} 5 \mathrm{al}$ expression, the coelomic epithelium expresses Six1, Six4, and Gata4, suggesting that these factors may preferentially contribute to the initiation of $\mathrm{Nr} 5 \mathrm{al}$ expression in gonadal progenitor cells. 
Genital ridges are extremely long and narrow structures along the anterior-posterior (A-P) axis. Recently, Hu et al. [34] reported that the anterior part of the monolayered coelomic epithelium expresses Gata4 at the onset of genital ridge formation (E9.25, 26-27 total somite stage). The Gata4 expression pattern in the coelomic epithelium, which precedes thickening and progresses in an $\mathrm{A}-\mathrm{P}$ direction, is well correlated with the A-P progression of genital ridge formation [34]. Soon after (E9.5, 0 tail somite stage), the coelomic epithelium begins to express $\mathrm{Nr} 5 \mathrm{a} 1$ and forms the thickened (multilayered) structure [42, 61]. Expression of $\mathrm{Nr} 5 \mathrm{a} 1$ is also extended in the A-P direction following the Gata4 expression pattern in the coelomic epithelium. At the anterior region, the coelomic epithelium is developmentally more advanced than that at the posterior region, in which the E10.4 (6 tail somite stage) anterior but not posterior coelomic epithelium has already become more than one layer of cells [34]. These findings suggest that the formation of the extremely long and narrow genital ridge begins from the anterior part of the coelomic epithelium, which is accompanied by Gata4 and subsequent Nr5a1 expression. The Gata4 upregulation pattern during genital ridge formation appears to be closely correlated with $\mathrm{Nr} 5 \mathrm{a} 1$ rather than Six1 or Six4. However, during the initial growth of gonadal precursor cells, Six 1 and Six4 expression is colocalized with high $\mathrm{Nr} 5 \mathrm{a} 1$ expression and they are considered to directly transactivate $\mathrm{Nr} 5 \mathrm{al}$ in the coelomic epithelial cells at E11.0 (12 tail somite stage). It is likely that Gata4 facilitates the initial activation of $\mathrm{Nr} 5 \mathrm{al}$, while Six 1 and Six 4 may contribute to the maintenance of high Nr5al expression in the progenitors. Nonetheless, a proportion of the cells that express Gata4, Six1, or Six4 appear to become Nr5al-positive progenitor cells in the coelomic epithelium. Further studies are required to uncover the precise mechanisms underlying the restricted upregulation of $\mathrm{Nr} 5 \mathrm{al}$ in the subpopulation of coelomic epithelial cells. Furthermore, identification of the upstream regulator of Gata4, Sixl, and Six4 remains to be elucidated in the coelomic epithelium.

\section{Sry expression and subsequent Sox 9 upregulation}

\section{Overview of sex determination in bipotential gonads}

The fate of the embryonic gonad is determined by differentiation of somatic cells into Sertoli or granulosa cells. In bipotential gonads, the formation of Sertoli cells promotes the testicular differentiation program, whereas formation of granulosa cells promotes the ovarian differentiation program. In most of mammalian sex determination, expression of the Y-linked gene Sry shifts the bipotential embryonic gonad toward a testicular fate [12-14]. The primary function of Sry is to induce differentiation of pre-Sertoli cells, which is essential for testis differentiation of the bipotential gonad (Fig. 2). Sry shows a strictly controlled and limited spatiotemporal expression pattern in the precursors of Sertoli cells. In mouse genital ridges, Sry is first expressed at around E11.0 (12 tail somite stage), reaches peak levels of expression at E11.5 (18 tail somite stage), and is extinguished shortly after E12.5 (30 tail somite stage). Expression of Sry begins in the central region of genital ridges and then extends to the anterior and posterior poles. Thereafter, Sry expression extinguishes in the anterior and central regions, and becomes restricted to the posterior region before it completely disappears in the genital ridges. At about $4 \mathrm{~h}$ after initiation of Sry expression, Sox9 is upregulated in Sertoli cell precursors [62-69]. Transgenic mouse analyses have demonstrated that the expression of either Sry or Sox 9 in the bipotential gonad is sufficient to induce the male developmental program [13, 70-72].

Roles of Sry and Sox9 in testis determination

Sry and Sox 9 are members of the Sox family of developmental transcription factors that contain an amino acid motif known as the HMG domain (for reviews [73, 74]). This HMG motif enables Sox family proteins to bind to the DNA consensus sequence (A/T)ACAA(T/A) with high affinity [75]. Most SRY mutations found in human patients showing maleto-female sex reversal affect the ability of SRY to bind and bend DNA [76-80]. SRY mutation analysis of its C-terminal domain suggests that the SRY C-terminal domain may contribute to the conformation of SRY and a change in conformation may influence SRY functions [81]. There is a nuclear localization signal (NLS) at the N-terminal end of the SRY HMG box, and SRY mutations in this NLS result in a reduction of nuclear importation, which partially explains some cases of human sex reversal [82, 83].

A Sox 9 transgene has been found to promote the testicular differentiation program instead of Sry [70-72]. Thus, the essential function of Sry in testis determination may be upregulation of Sox 9 only. Another possibility is that the Sox 9 transgene product activates not only endogenous Sox9, but also other Sry target genes that are required to induce testicular development. Therefore, Sry is dispensable for testicular development in Sox9 transgenic embryos. Several genes have been demonstrated as prospective downstream targets of Sry and/or Sox 9 by ChIP assays, such as Podl, the secreted growth factor neurotrophin 3 (Ntf3), and secreted glycoprotein cerebellin precursor $4(C b \ln 4)$ [84-87]. However, there is no direct evidence of the possible involvement of these genes in the initial testis determination (Sertoli cell differentiation) that might be regulated by Sry, but not Sox9, in XY gonads [40, 


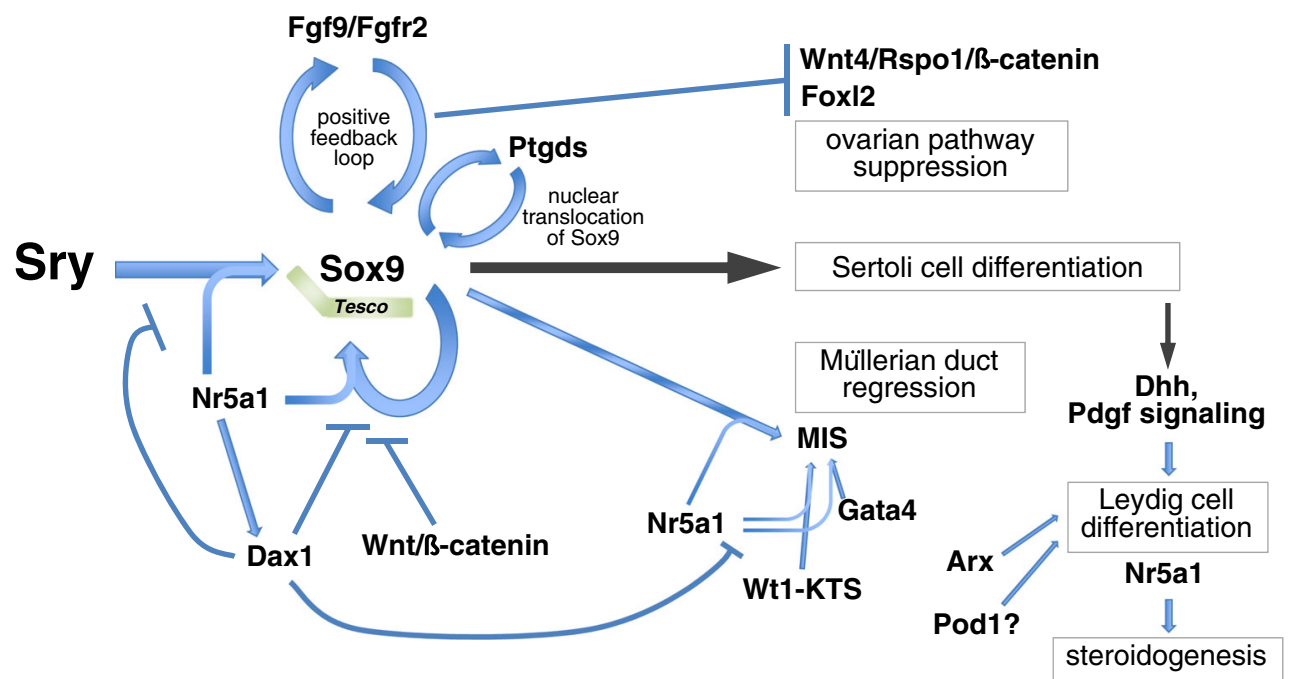

Fig. 2 Sry and the transcriptional network that governs testis determination. In mice, expression of a single genetic trigger, the Y-linked gene Sry, induces differentiation of pre-Sertoli cells. Sry directly transactivates Sox 9 through the core element of the testisspecific enhancer region of Sox9 (Tesco) together with Nr5a1. Sox9 itself also contributes to the maintenance of $\operatorname{Sox} 9$ expression through Tesco together with Nr5a1. Excess Dax1 interferes with Sox9 upregulation, likely through inhibition of the binding of Nr5a1/Sry or Nr5a1/Sox9 proteins to Tesco. Although Dax1 interferes with the activity of Nr5a1, Dax1 expression depends on Nr5a1 activity. Sox9 upregulates Fgf9 expression, and FGF9 in turn establishes the Sox9FGF9 positive feedback loop through FGF receptor 2 (FGFR2), which maintains a high level of Sox9 expression. The Sox9-FGF9 positive

88, 89], except for Sox9 [90, 91]. Nonetheless, further studies will be required to determine the functions of Sry in testis determination.

\section{Upstream regulatory factors of Sry}

Although a Sox 9 transgene promotes the testicular differentiation program in bipotential gonads, primary sex determination in mammals is commenced by the presence or absence of the Y chromosome. Sox 9 is located on an autosome (chromosome 11 in the mouse genome), whereas Sry is on the Y chromosome. Therefore, the Y-linked gene Sry is the single genetic trigger that determines testis formation in the bipotential gonad of XY mammals. A $14.6 \mathrm{~kb}$ Sry transgene construct can mimic endogenous Sry expression in transgenic mouse embryos [62]. However, this construct lacks the cis-acting regulatory element that is necessary for transcriptional silencing after E 12.5. Furthermore, there are no reports of specific cis-acting regulatory elements that are implicated in transcriptional activation of Sry in vivo. In vitro biochemical analyses have demonstrated that WT1, NR5A1, SOX9, GATA4, and SP1 bind to and transactivate human or pig SRY promoters [92-96]. There is limited knowledge of the regulation of feedback loop also acts to suppress ovary-specific WNT4/R-spon$\operatorname{din} 1(\mathrm{Rspo} 1) / \beta$-catenin signaling activity. Sox 9 expression also interferes with upregulation of the ovarian gene Foxl2. In addition, Sox 9 upregulates Ptgds, and the signaling activity of Ptgds promotes nuclear translocation of Sox9 to facilitate Sertoli cell differentiation. Together with Nr5a1, Sox9 regulates activation of MIS that promotes regression of Müllerian ducts. MIS is also regulated synergistically by Nr5a1 and Wt1-KTS, as well as Gata4. Sertoli cells express Dhh that is required for specification of the fetal Leydig cell fate. Pdgf secreted by Sertoli cells is also required for fetal Leydig cell differentiation. Arx and probably Pod 1 are involved in regulation of Leydig cell differentiation. Male steroid hormones are synthesized by Leydig cells, which is mainly regulated by $\mathrm{Nr} 5 \mathrm{al}$

Sry expression in vivo. Therefore, genetic inactivation of genes, especially genes encoding some key transcription factors, results in reduced Sry expression and a sex reversal phenotype. The key genes involved in Sry expression are outlined in "Box 2". For example, although Wt1-KTS binds to the $S R Y$ promoter region [93], testicular differentiation markers are expressed in a small cluster of cells in mouse embryos that specifically lack Wt1-KTS [32]. This finding suggests that Wt1-KTS is unlikely to be required for Sry expression in testis determination. In contrast, abolition of the Wt $1+K T S$ isoform results in reduced Sry levels and a sex-reversal phenotype [32]. Wt1+KTS does not transactivate the Sry promoter in vitro $[93,96]$, but is reported to function to increase the levels of unspliced RNA containing either a cellular or viral constitutive transport element and to specifically promote translation of this unspliced RNA [97]. These findings suggest that Wt1+KTS is implicated in the post-transcriptional regulation of Sry mRNA in testis determination.

Embryos lacking a gene encoding a zinc finger protein Friend of GATA-2 (Fog2, also known as Zfpm2) and those containing homozygous mutant alleles of $\mathrm{Gata}^{k i}$, which abrogate the interaction of Gata4 with Fog, show reduced Sry expression and a sex-reversal phenotype [98]. These 
findings suggest that the interaction of Gata4 and its cofactor Fog2 is critical for Sry activation. We also found that Six 1 and Six 4 play crucial roles in Sry expression by upregulation of Fog2 in the coelomic epithelium. XY Six $1^{-1-} ;$ Six $^{-1-}$ gonads show remarkable downregulation of Sry and subsequent impaired testicular differentiation accompanied by reduced Fog 2 expression. Reporter assays in the M15 mouse mesonephric cell line and ChIP assays using embryonic tissues containing gonads further demonstrated that Fog 2 is a direct target of Six 1 and Six 4 [42].

Recently, it was reported that stage-specific Sry upregulation is mediated by transient activation of Gata4 via its phosphorylation. In a forward genetic screen of mouse homozygous mutants exhibiting consistent $\mathrm{XY}$ gonadal sex reversal, Bogani et al. (2009) identified a recessive boygirl (byg) mutation. The byg mutation is an A to T transversion that introduces a premature stop codon in the gene encoding mitogen-activated protein kinase (Mapk) kinase kinase Map3k4 (also known as Mekk4). On the C57BL/6J background, E11.5 byg/byg gonads show impaired growth and a dramatic reduction of Sry expression. MKK4, a direct target of MAP3K4 and p38 MAPK, is activated in the coelomic region of the E11.5 XY wild-type gonad, suggesting that MAPK signaling may be involved in promoting gonadal somatic cell growth and regulation of Sry expression [99]. MAP3K4 interacts with several proteins including members of the growth arrest and DNA damage response protein family [100]. Mice lacking a member of this family, Gadd45g (Gadd45 ${ }^{-\prime-}$ ), also show XY gonadal sex reversal caused by disruption to Sry expression [101, 102]. Gadd45g and Map3k4 genetically interact during sex determination, and transgenic overexpression of Map $3 \mathrm{k} 4$ rescues gonadal defects in $\mathrm{Gadd} 45 \mathrm{~g}^{-/-}$embryos. In Gadd $45 g^{-/-}$gonads, there is a delay and reduction in Sry expression, despite the fact that the Sry promoter is demethylated and occupied by active histone marks. Instead, the sex-reversal phenotype in both Gadd45g and Map3k4 mutants is associated with reduced phosphorylation of p38 MAPK and Gata4. Conditional inactivation of the genes encoding $p 38 \alpha$ and $p 38 \beta$ Mapks also causes embryonic XY gonadal sex reversal due to reduced levels of Sry expression. Furthermore, reduced levels of phosphorylated Gata4 are found in both Gadd45g and Map3k4 mutant XY gonads, and Gata4 binds to the Sry promoter in vivo in a MAPKdependent manner [101, 102]. Remarkably, Gadd45g shows increased expression at the onset of Sry expression in the genital ridges of both sexes. This increased expression of Gadd45g is considered to regulate stage-specific Sry expression by interacting with Map3k4 [101, 102]. Sry is also expressed in non-gonadal tissues such as dopamineabundant regions of the brain. It has been recently reported that the Sry upregulation pathway in Sertoli cell precursors appears to be conserved in neuronal cells of the brain [103].
Treatment with a dopaminergic toxin, 6-hydroxydopamine, induces an increase of Gadd45g expression and activates the Gadd45g-Map3k4-p38 MAPK pathway, resulting in $S R Y$ upregulation in human male neuroblastoma-derived cell line M17 cells [103].

Histone modification factors are also reported to be involved in Sry expression. Mouse embryos lacking the polycomb group gene $C b x 2$ show reduced Sry expression [35]. However, the genetic interaction between $C b x 2$ and Sry is unclear. Recently, Kuroki et al. [104] reported that male-to-female sex reversal in mice lacking the histone $\mathrm{H} 3$ lysine 9 (H3K9) demethylase Jmjdla (also known as Tsgal $J h d m 2 a / K d m 3 a)\left(\mathrm{Jmjdla}^{-/}\right)$is accompanied by reduced expression of Sry. Jmjdla ${ }^{-1-}$ mice show abnormal sex differentiation depending on the genetic background. On the CBA genetic background, $88 \%$ of XY Jmjdla $a^{-1}$ mice show abnormal sex differentiation, whereas only $14 \%$ of $\mathrm{XY} J \mathrm{Jjdla}^{-/-}$mice on the B6 genetic background show such a phenotype. At E11.5, Jmjd1a is expressed in gonadal somatic and germ cells, but not mesonephric cells. Jmjdla shows the highest expression level among the genes encoding enzymes involved in the maintenance of H3K9 methylation in E11.5 gonadal somatic cells. Jmjd1a expression increases from E10.5 and reaches a peak at around E11.5. Interestingly, inactivation of Jmjdla is unlikely to influence the expression of known Sry regulators. Instead, Jmjd1a binds to regulatory regions within the Sry locus as shown by ChIP assays using purified Nr5a1positive gonadal somatic cells from E11.5 gonads. Furthermore, inactivation of Jmjdla leads to a significant increase in the levels of H3K9 demethylation (H3K9me2) within the Sry locus without changing histone H3 occupancy and the H3K9me2 levels of the Sox9 locus [104]. Therefore, these findings suggest a crucial role of a histone demethylase in Sry expression. It is likely that the H3K9me2 marks may limit the ability of the transcriptional factors (i.e., their accessibility or initiation of transcription) to facilitate the Sry upregulation, because Sry regulators are considered to be normally present in Jmjdla ${ }^{-1-}$ gonads.

Collectively, this recent progress has revealed the molecular network that governs Sry upregulation (Fig. 3). Before the onset of Sry expression, H3K9me2 levels are reduced in the Sry locus, which is mediated by stage-specific upregulation of Jmjd1a, allowing initiation of Sry expression by the transcriptional factors. Fog2 expression is also upregulated in the coelomic epithelium by Six 1 and Six 4 before the onset of Sry expression. Gata4 is transiently activated by the Gadd45g-Map3k4-p38 MAPK pathway. Subsequently, the phosphorylated Gata4 and Fog2 protein complex may bind to the Sry promoter and activate Sry expression in a stage-specific manner. In addition, the Wt1+KTS isoform may contribute to the post-transcriptional regulation of Sry mRNA (Fig. 3). 


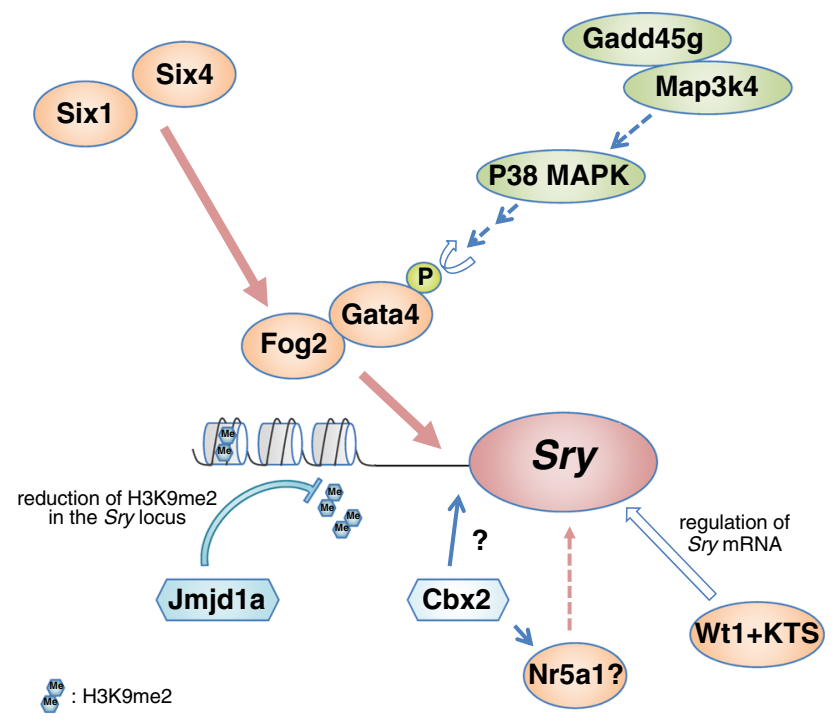

Fig. 3 Model for Sry upregulation. Before the onset of Sry expression, a reduction in the $\mathrm{H} 3 \mathrm{~K} 9 \mathrm{me} 2$ levels of the $S r y$ locus is mediated by stage-specific upregulation of the H3K9 demethylase Jmjd1a, which may allow Sry upregulation by transcriptional factors. Interactions of Gata4 with its co-factor Fog2 are critical for Sry activation. Fog2 is upregulated in the coelomic epithelium by Six1 and Six4 before the onset of Sry expression. Gata4 is transiently activated by the Gadd45g-Map3k4-p38 MAPK pathway because of the stagespecific Gadd45g upregulation. Subsequently, the phosphorylated Gata4 and Fog2 protein complex may bind to the Sry promoter and activate Sry expression in a stage-specific manner. The Wt1+KTS isoform may contribute to the post-transcriptional regulation of Sry mRNA. The polycomb group gene $C b x 2$ is required for Sry upregulation, but the genetic interaction between $C b \times 2$ and Sry is unclear. In addition, Cbx2 promotes $N r 5 a 1$ upregulation, and $\mathrm{Nr} 5 \mathrm{a} 1$ is proposed to be one of the upstream regulators of Sry

Upregulation and maintenance of Sox9 expression

Sry shows a strictly controlled and limited spatiotemporal expression pattern in XY gonads. To upregulate Sox 9 and promote subsequent testicular differentiation, the appropriate timing and a sufficient level of Sry expression are thought to be required. For example, a mouse strain combination study revealed that the $\mathrm{Y}$ chromosome from natural populations of Mus domesticus captured in $\mathrm{Val}$ Poschiavo, Switzerland (termed $\mathrm{Y}^{\mathrm{POS}}$ ), failed to promote normal differentiation of the testis when crossed with a C57BL/6 J background [105]. Some B6- $\mathrm{Y}^{\mathrm{POS}}$ mice show a range of phenotypes in the impairment of testis development, such as hermaphroditism with ovotestes and complete sex-reversal phenotypes. In $\mathrm{B} 6-\mathrm{Y}^{\mathrm{POS}}$ mice, there is a definite delay and likely reduction in Sry expression, resulting in impaired Sox 9 expression [106]. Ovotestes of B6- $\mathrm{Y}^{\mathrm{POS}}$ mice show partial testis cord formation with stable high expression of $\operatorname{Sox} 9$ in the central region, whereas the ovarian somatic cell marker ovarian gene Forkhead box L2 (Foxl2) is expressed in the pole regions
[107]. Such high expression of Sox9 in the central region of the gonad is considered to reflect the Sry expression that begins in the central region of the gonad. Because of the delay in Sry expression, only the central region, but not the pole regions, expresses Sry at a sufficient level in the appropriate time window, allowing the cells to upregulate Sox 9 and maintain the high level of expression needed to promote subsequent testicular differentiation.

Hiramatsu et al. [108] established a heat shock-inducible Sry transgenic mouse system that allows induction of testis development in cultured XX genital ridges at various time points during development. Using this system, they showed that the ability of Sry to determine testis development is limited to a narrow time window of $6 \mathrm{~h}$, approximately from E11.0 to 11.25 (12-15 tail somite stages) [108]. Interestingly, after this critical time period, ectopic Sry induction initially induces Sox 9 expression, but the high level of Sox 9 expression is not maintained, resulting in ovarian differentiation. This finding suggests that the action of Sry in the narrow time window to drive testicular development is likely to be limited by maintenance of the high level of Sox 9 expression rather than the initial upregulation of Sox9 [108].

Furthermore, the presence of an appropriate number of Sry-expressing pre-Sertoli cells in the XY gonad might be crucial to maintain the high level of Sox 9 expression and subsequent testicular differentiation. Proliferation of gonadal somatic cells at E11.25-11.5 (a specific 8-h period), which coincides with the initiation of Sry expression, is considered to be required to recruit an appropriate number of Sry-expressing pre-Sertoli cell precursors from the coelomic epithelium, leading to testis cord formation in developing XY gonads [29, 109]. In addition, FGF9 has been reported to promote the male-specific proliferation of Sertoli cell precursors between E11.0 and 11.5 [110, 111]. Abolition of $W t 1+K T S$ isoform results in reduced Sry levels and produces the male-to-female sex-reversal phenotype [32]. It is accompanied by a decrease in cell proliferation of Sry-expressing cells in the coelomic epithelium, which is rescued by the addition of exogenous FGF9 to the cultured gonad [112]. XY Six1 $1^{-/-}$; Six $4^{-/-}$ gonads show impaired growth of gonadal progenitor cells and a remarkable reduction in the number of Sry-expressing cells [42]. In accordance with the center-to-pole Sry expression pattern, Sox9-positive cells are initially and predominantly found in the central region and then limited to the pole regions, especially at the posterior region of the gonads, and eventually disappear in XY Six1 $1^{-/-}$; Six $4^{-/-}$ gonads. Forced Sry transgene expression in XY Sixl ${ }^{-/-}$; Six $4^{-/-}\left(\right.$Six $\left.1^{-/-} ; \operatorname{Six}^{-/-} ; \mathrm{Sry}^{\mathrm{Tg} /+}\right)$ gonads rescues the impaired testicular development, which is accompanied by stable high expression of $\operatorname{Sox} 9$, but not the initial progenitor cell growth. Even in the genital ridge with fewer initial 
gonadal precursor cells, Sry transgene expression might increase the number of Sry-expressing cells. Therefore, maintenance of the high expression level of Sox9 and subsequent testicular differentiation are rescued in $\mathrm{XY}$ Six $1^{-1-} ;$ Six $^{-/-} ;$Sry $^{T g /+}$ embryos [42].

Sekido and Lovell-Badge [59] revealed that Sry directly transactivates Sox9 through the $3.2 \mathrm{~kb}$ testis-specific enhancer region of Sox 9 (Tes) or $1.4 \mathrm{~kb}$ of its core element (Tesco), together with Nr5a1 in pre-Sertoli precursor cells. ChIP assays show that Sry and Nr5al directly bind to several sites within the Sox9 enhancer region in vivo. Mutations in these sites abolish the $\operatorname{Sox} 9$ enhancer activity in transgenic mice, suggesting that Sry and Nr5a1 synergistically upregulate Sox9 enhancer activity [59]. Sry may contribute to the initial upregulation of Sox9, but not its maintenance at later stages, because Sry shows transient upregulation at around E11.5 and then disappears by E12.5 in genital ridges. Alternatively, Sox 9 itself may contribute to the maintenance of Sox9 expression through the Tes together with Nr5a1 [59] (Fig. 2). In addition, an excess amount of the $\mathrm{X}$-linked orphan nuclear hormone receptor Daxl (also known as $\mathrm{NrObl}$ ) causes an $\mathrm{XY}$ ovotesticular disorder of sex development. Excess Dax 1 interferes with Sox 9 upregulation by likely inhibiting Nr5a1/Sry or Nr5a1/ Sox9 protein binding to the testis-specific enhancer region of Sox9 [113]. Although Dax1 interferes with the activity of Nr5a1 in Sox9 upregulation, Dax1 expression depends on Nr5a1 activity [114] (Fig. 2). Although mouse Tes shows testis-specific enhancer activity [59], human TES is unlikely to show such activity in transgenic mice, and mutations have not been identified in human TES, which cause DSD (for a review [24]). It suggests that there might be uncharacterized $S O X 9$ regulatory elements in addition to TES. It has been reported that the regulatory region of SOX9 spans more than $2.5 \mathrm{Mb}$ upstream and downstream of the SOX9 open reading frame [91, 115]. In addition, a dominant insertional mutation, Odsex (Ods), in which XX mice carrying a $150 \mathrm{~kb}$ deletion (approximately $1 \mathrm{Mb}$ upstream of Sox9) develop as XX males lacking Sry, is accompanied by Sox 9 upregulation [70]. Recently, a noncoding genomic region of the Sox9 promoter has been reported to regulate sex determination [116]. In B6- $\mathrm{Y}^{\mathrm{POS}}$, the presence of a $55 \mathrm{Mb}$ congenic region on chromosome 11, a flanking region of Sox9, is known to protect against B6- $\mathrm{Y}^{\mathrm{POS}}$ sex reversal in a dose-dependent manner. Arboleda et al. [116] further demonstrated that a $1.62 \mathrm{Mb}$ congenic region of the Sox 9 promoter, which is likely derived from the semi-inbred strain POSA, protects against B6- $\mathrm{Y}^{\mathrm{POS}}$ sex reversal and promotes Sox9 expression, thereby driving testis development within the $\mathrm{B} 6-\mathrm{Y}^{\mathrm{POS}}$ background. Further analyses of mutations to identify the novel testis-specific enhancer element of SOX9 will be needed in human patients with DSD.
Sox9 is also reported to be upregulated in a transgenic mouse overexpressing Sox3 [117]. Sox3 is an $\mathrm{X}$-linked gene and shows high sequence similarity with Sry. Sox 3 is not expressed in male or female developing gonads, and loss-of-function mutations in Sox3 do not affect sex determination in humans or mice. However, in the Sox3 overexpressing transgenic mouse embryo, Sox3 shows ectopic expression in bipotential gonads and induces Sox9 upregulation, thereby driving female-tomale sex reversal [117]. Three 46, XX DSD patients have also been identified with genomic rearrangements related to SOX3. Two of them are duplications including SOX3, and the other is a deletion of the putative upstream regulatory region of SOX3 [117]. Thus, SOX3 and SRY are considered to be functionally interchangeable to upregulate SOX9 expression in testis determination. This finding also supports the hypothesis that the Y-linked gene $S R Y$ may have evolved from the $\mathrm{X}$-linked gene SOX3 (for a review [118]). Sox9 is also known to be upregulated in a transgenic mouse overexpressing another Sox family gene, Sox10, thereby driving female-to-male sex reversal [119]. Sox9, Sox10, and Sox8 are SoxE family genes. Sox8 and Sox10 are upregulated in the XY developing gonad shortly after Sox9 expression $[119,120]$. Although neither inactivation of Sox8 nor Sox10 in mice results in abnormal sexual development [119, 121], double-mutant mouse studies of $\operatorname{Sox} 8$ and Sox9 imply that they have functional redundancy in testicular differentiation [122, 123]. In addition, a duplication in the region encompassing SOX10, among a number of other genes, has been identified in human 46,XX patients with DSD $[124,125]$. Collectively, not only the misexpression of $S R Y$, but also SOX family genes is considered to promote testicular differentiation by upregulation of SOX 9 or in place of $S O X 9$ expression in DSD patients.

\section{Testicular differentiation of the gonad after Sox9 upregulation}

\section{Overview of sex differentiation of gonads}

During the past few decades, we have gained considerable knowledge of the regulatory gene network in testicular differentiation promoted by Sox9 (for reviews, [19-26]). Sox9 directly or indirectly upregulates Fgf9 expression, and FGF9 in turn upregulates Sox9 expression [126]. Therefore, $\operatorname{Sox} 9$ is first upregulated by transient expression of Sry in pre-Sertoli cells, and then the Sox9-FGF9 positive feedback loop maintains the high level of $\operatorname{Sox} 9$ expression during testicular differentiation of XY gonads (Fig. 2). Mice lacking FGF receptor 2 ( $F g f r 2)$ show partial 
XY sex reversal, which phenocopies $F g f 9$ mutants, suggesting that FGF9 signaling through FGFR2 is required for testicular development $[127,128]$. FGF9 is also known to promote the survival of germ cells and prevents them from entering meiosis $[129,130]$. Sox 9 also binds directly to the promoter of Ptgds encoding prostaglandin D2 synthase to induce upregulation, and its signaling activity promotes nuclear translocation of Sox 9 to facilitate Sertoli cell differentiation [69, 131, 132]. Together with Nr5a1, Sox9 regulates the activation of MIS that promotes regression of Müllerian ducts [58]. MIS is also regulated synergistically by Nr5a1 and Wt1-KTS, as well as Gata4, while Dax1 antagonizes these synergistic effects [133-135] (Fig. 2).

The antagonism between testicular and ovarian genes is known to regulate sex differentiation of the gonad (Fig. 2). In XY gonads, the testis-specific Sox9-FGF9 positive feedback loop acts to suppress ovarian gene expression, leading to promotion of testicular differentiation. In contrast, ovary-specific canonical WNT signaling represses the testis-specific Sox9-FGF9 positive feedback loop in XX gonads, enabling commencement of ovarian differentiation. For example, conditional inactivation of Sox9 in XY embryonic gonads causes upregulation of ovarian gene Foxl2 [136]. Conversely, XX embryonic gonads lacking the ovarian gene Wnt4 are partially masculinized with transient Sox9 activation. Ovary-specific WNT4/R-spondin1 (Roof plate-specific Spondin 1, Rspo1)/ $\beta$-catenin signaling represses the testis-specific Sox9-FGF9 positive feedback loop during ovarian differentiation of XX gonads [126, 137-139]. Furthermore, ectopic activation of WNT/ $\beta$-catenin signaling in XY gonads leads to the loss of Nr5a1 binding to the Sox9 enhancer region, thereby inhibiting Sertoli cell differentiation [140] (Fig. 2). Remarkably, coexpression of testis-specific Sox9 and ovary-specific Fox12 has never been found in the same cell, even in a sex-disordered gonad. This observation is the result of the antagonism between testicular and ovarian genes, which regulates sex differentiation of the supporting cell lineage in the gonads.

As described above, the identification of several key genes that regulate sex determination has facilitated our understanding of the regulatory gene network in testicular differentiation. However, our current knowledge still cannot fully explain some cases of sexual development disorders. It is likely that the sexual fate decision in the developing gonad depends on a complex network of interacting factors that converge at a critical threshold. Munger et al. [141, 142] has performed comprehensive analyses of expression quantitative trait loci to elucidate the transcriptional network underlying sex determination. This approach identified autosomal regions that control the expression of many sex-related genes such as Sry and Sox9 [141]. Furthermore, gene- silencing analyses of candidate genes revealed that Limdomain only 4 (Lmo4) is a novel regulator of sex determination upstream of Nr5al, Sox9, Fgf9, and Col9a3 [142]. Further comprehensive approaches will be needed to elucidate the regulatory gene network that governs testicular differentiation.

\section{Cell lineage derivation in gonads}

\section{Supporting cell lineages (Sertoli cells and granulosa cells)}

During genital ridge formation, the first population of somatic cell progenitors from the coelomic epithelium migrates mediodorsally to form the bipotential gonad. In $\mathrm{XY}$ gonads, some of the Nr5a1-positive daughter cells derived from the coelomic epithelium express Sry to become Sertoli cell precursors [27, 29, 62, 63, 68]. This ability of the coelomic epithelium to give rise to Sertoli cells is developmentally regulated by E10.5 ( 8 tail somite stage). When the cells are labeled by the fluorescent lipophilic dye at E11.5 (18-20 tail somite stages), the coelomic epithelial cells no longer become Sertoli cells. Instead, the coelomic epithelial cells that migrate into the gonad remain outside of the testis cords and become interstitial cells [27]. During genital ridge formation at around E10.0-11.5, two kinds of Nr5a1-positive cell populations, Nr5a1 ${ }^{\text {high }}$ and $\mathrm{Nr} 5 \mathrm{a} 1^{\text {low }}$, appear to be in the coelomic epithelium and the mediodorsal region where genital ridges are formed [42]. Because Nr5a1 is known to act dose dependently, the differential expression level of $\mathrm{Nr} 5 \mathrm{a} 1$ in progenitors may also be associated with cell fate commitment to the Sertoli cell lineage.

At around E12.5, there is drastic reorganization of XY gonads, leading to a significant difference in the morphologies of the testis and ovary. In XY gonads, Sertoli cells polarize and aggregate around germ cells to form the tubular testis cord. The testis cord is composed of Sertoli and germ cells layered by peritubular myoid cells. Sertoli cells interact with and support the growth and differentiation of germ cells during gametogenesis. Sertoli cells express Cyp26b1 encoding the P450 catabolic enzyme, which is activated synergistically by Sox9 and Nr5a1 [143]. In XY gonads, male-specific expression of Cyp26b1 mediates degradation of retinoic acid (RA), which inhibits germ cells from entering meiotic division by preventing exposure to RA [144, 145].

In XX gonads, progenitor cells from the coelomic epithelium show no obvious fate restriction and are unlikely to contribute to the supporting cell lineage (granulosa cells) at the embryonic stage $[27,29]$. Instead, during the perinatal and early postnatal periods, coelomic epithelial cells ingress to the ovarian cortex and give rise to granulosa cells [146]. Subsequently, there is formation of the primordial 
follicles in which a single layer of granulosa cells completely surrounds and nurtures individual germ cells. In contrast to testis cord formation, follicular formation is critically dependent on the presence of germ cells [147, 148]. Specification of pre-granulosa cells begins in XX gonads, which is accompanied by ovarian-specific Foxl2 expression at around E12.5 [149]. Repression of Sox9 by the ovary-specific WNT signaling activity enables Foxl2 upregulation in the supporting cell lineage of XX gonads.

\section{Endocrine cell lineages (Leydig and theca cells)}

In XY gonads, interstitial Leydig cells are derived from the coelomic epithelium and gonad-mesonephros border cells [150]. Early differentiation and expansion of the fetal Leydig cell lineage are regulated by Sertoli cells. For example, signaling activity of Desert Hedgehog (Dhh, also known as Patched 1), which is expressed in Sertoli cells, is required for specification of the fetal Leydig cell fate [151]. Signaling by the growth factor PdgfA, which is secreted from Sertoli cells, through its receptor Pdgfra in the interstitium is required for fetal and adult Leydig cell differentiation [152, 153]. In addition, the X-linked $a r$ istaless-related homeobox gene (Arx) is implicated in the regulation of Leydig cell differentiation [154]. Ectopic Nr5al upregulation in Podl lacZ/lacZ gonads leads to a remarkable increase in the number of presumptive fetal Leydig cells [40], suggesting that Nr5a1 may contribute to fetal Leydig cell formation. Testosterone, the male sex steroid hormone, is synthesized by Leydig cells through the coordinated action of steroidogenic enzymes, many of which are regulated by Nr5a1. Subsequently, endocrine effects of the testosterone promote the differentiation of secondary male sexual characteristics of individuals. Testosterone, which functions through the androgen receptor (AR), masculinizes the rest of the body, including male-specific differentiation of the genital tract, external genitalia, and brain (for a review [26]). X-linked ATR-X (alpha thalassemia, mental retardation, X-linked) syndrome in males is characterized by mental retardation, facial dysmorphism, alpha thalassemia, and urogenital abnormalities including small testes. ATR-X modulates AR-dependent gene expression in spermatogenesis, which is important for the proliferation and survival of fetal Sertoli cells [155]. Fetal Leydig cells are also reported to produce a member of the TGF- $\beta$ superfamily, activin A, which regulates Sertoli cell proliferation and fetal testis cord expansion [156].

In XX gonads, when the follicle has two layers of granulosa cells, theca cells are formed and localize to the outer surface of the follicle. Theca cells are derived from mesenchymal precursor cells in the ovarian stroma adjacent to the developing follicles. Currently, the factors that regulate theca cell differentiation are unknown. In association with ovarian follicles, theca cells play crucial roles in supplying sex steroid hormones required for oocyte development and physiological homeostasis of the body (for a review [157]).

\section{Other cell lineages}

After E11.5, a second population of somatic cells from the neighboring mesonephros migrates into the $\mathrm{XY}$, but not XX gonad [158]. The migrated mesonephric cells in the testis are required to form and pattern the testis cords. Recent findings suggest that this cell population becomes endothelial cells exclusively and is incapable of differentiation into Sertoli cells $[159,160]$. These endothelial cells contribute to vascular network formation in the XY gonads. The interstitium of the XY gonad also contains other uncharacterized cell types. For example, a cell population positive for the soluble integrin-binding protein Mfge 8 is specifically localized to the border region between the gonads and mesonephros of the E10.0 coelomic epithelium. Subsequently, the Mfge8-positive cells expand around the border region and contribute to a previously uncharacterized somatic cell type that is distinct from Sertoli cells, Leydig cells, peritubular myoid cells, and the endothelial cells [161].

\section{Functional interaction between somatic cells and germ cells in the gonad}

\section{Initiation of germ cell sexual differentiation}

The gonad is an essential organ for differentiation of germ cells into mature gametes in both sexes, which are required to produce the next generation. Supporting Sertoli and granulosa cells interact with and nurture the germ cells. In testes, germ cells differentiate into sperms, whereas in ovaries, germ cells differentiate into oocytes.

PGCs settle into the genital ridge and interact with gonadal somatic cells at around E10.0 before sex determination occurs. Thereafter, male-specific RA degradation by Cyp26b1 prevents germ cells from entering meiotic division in XY gonads, but not in the XX gonad at around E13.5 [144, 145]. The interaction with gonadal somatic cells is considered to facilitate germ cell differentiation in which PGCs in the gonads exit their pluripotent and migratory states, and acquire competence to initiate sexual differentiation and enter meiosis. For example, PGCs in gonads start expressing germ cell-specific genes, such as genes encoding the RNA-binding protein dazl (deleted in azoospermia-like) and RNA helicase $m v h$ (mouse vasa homolog, also known as $D d x 4$ ). Moreover, co-culture of 
embryonic germ (EG) cells with gonadal somatic cells induces $m v h$ upregulation. dazl and $m v h$ are essential for germ cell development in adult testes and important for gonadal germ cell development [162-169]. On the other hand, expression of pluripotency-related genes, such as Pou5f1 (also known as oct-3/4) and Alpl [also known as Akp2 encoding tissue non-specific alkaline phosphatase (TNAP)], is gradually decreased in gonadal PGCs. Recent whole-genome bisulfite sequencing has also shown that global loss of DNA methylation occurs in migratory PGCs, but some resistant regions become demethylated in PGCs only after they colonize the gonads [170]. These findings suggest that the interaction with gonadal somatic cells facilitates the initiation of sexual differentiation of germ cells, but its precise regulatory mechanisms remain to be elucidated.

Recently, PGC-like cells (PGCLCs) have been derived from mouse embryonic stem cells (ESCs) or inducible pluripotent stem (iPS) cells in vitro, which are capable of generating a live organism in both sexes [171-173]. However, the generation of functional gametes from PGCLCs requires the microenvironment of gonadal somatic cells. To generate functional sperms, XY PGCLCs can be injected into neonatal testes [172], whereas oocyte generation from XX PGCLCs requires co-culture with female gonadal somatic cells [171]. On the other hand, Buganim et al. [174] have generated induced embryonic Sertoli-like cells (ieSCs) by direct reprogramming of mouse embryonic fibroblasts (MEFs). Concomitant expression of five transcription factors, Nr5a1, Wt1, Gata4, Sox9, and Dmrt1, efficiently reprograms MEFs into ieSCs. These ieSCs facilitate germ cell survival in culture and contribute to the Sertoli cell population in vivo [174]. Such induced cells may be useful materials not only to perform biochemical studies of Sertoli cell differentiation, but also to establish in vitro gametogenesis systems. Because in vitro generation of fertile sperm is possible in cultured neonatal mouse testes [175], it is worthwhile testing the use of induced cells instead of endogenous cells.

Plasticity of male and female supporting cells

Recently, the plasticity of the fate of male and female supporting cells in adult gonads has been reported in mice. Conditional inactivation of Foxl2 in adult ovaries results in transdifferentiation of granulosa cells to Sertoli cells, which is accompanied by upregulation of some testicular genes including Sox9 [176]. Furthermore, the reciprocal transdifferentiation of Sertoli cells to granulosa cells is found in adult mouse testes with conditional inactivation by Nr5al-Cre or Dhh-Cre of a member of the DM domain transcription factor family,
Dmrt1 [177]. However, loss of either Foxl2 or Dmrt1 in embryonic gonads does not impair sex determination or differentiation of gonads until the perinatal stage [178180]. Therefore, these findings suggest that distinct mechanisms may control the maintenance of the supporting cell fate in adult mouse gonads and the determination of the supporting cell fate when sex determination occurs in embryonic gonads.

The forkhead transcription factor Foxl2, the HMG transcription factor Sox9, and the DM domain transcription factor Dmrtl are known to be evolutionally conserved among animal species in terms of gene structure, expression pattern, and their functions in sex determination (for a review [181]). Manipulation of these evolutionally conserved factors achieves postnatal cell fate reprogramming of the supporting cells in mouse adult gonads. Compared with ovarian-specific Foxl2 and testicular-specific Sox9, homologs of Dmrt1 occasionally show opposing functions in sex determination among animal species. For example, the Y-linked DM gene $D M Y$ acts as the testis-determining gene in some Medaka fish species [182], whereas W-linked $D M-W$ promotes ovarian development in Xenopus laevis [183]. ChIP assays of adult mouse testes have demonstrated that Dmrt1 directly binds to the regulatory regions of testicular genes [i.e., Sox8, Sox9, and the Ptgds receptor (Ptgdr)] and ovarian genes [Foxl2, Wnt4, R-spondin1, and the estrogen receptor $(E s r)$ ] [177]. Therefore, Dmrt1 may regulate the expression of both testicular and ovarian genes to maintain the Sertoli cell fate in adult mouse testes. In terms of regulating both testicular and ovarian genes, Dmrt1 functions appear to be partially conserved among animal species.

In contrast to the transdifferentiation of postnatal supporting cells, sex reversal of germ cells is unlikely to occur after sex determination, even in the atypical gonadal environment of mice. Recently, only two genes on the Y chromosome, the testis determinant factor Sry and spermatogonial proliferation factor Eif $2 s 3 y$, have been shown to enable differentiation of XX germ cells into a round spermatid-like cell type in the testes, which can give rise to the next generation by injection into an oocyte [184]. Further investigations will be needed to address the plasticity of male and female germ cells in gonads.

\section{Conclusions and prospects}

The bipotential genital ridge is an essential organ for sex determination of individuals. $\mathrm{Nr} 5 \mathrm{a} 1$ is a key transcriptional factor in the formation and development of genital ridges. 
The formation of the long and narrow genital ridge begins from the anterior part of the coelomic epithelium, and Gata4, Six 1, and Six4 contribute to Nr5al expression in the progenitor cells (Fig. 1). A proportion of these cells give rise to Sry-expressing Sertoli cells in XY gonads. Despite identification of $S r y$ as the testis-determining gene of mammals in 1990, mechanisms underlying the strictly controlled expression of Sry and its functions in sex determination are largely unknown. Recent findings have revealed that transcriptional networks and histone modification govern Sry upregulation (Fig. 3). Sry primes initial upregulation and subsequent maintenance of $\operatorname{Sox} 9$ expression at a high level for testis determination. It has been suggested that appropriate timing and a sufficient level of Sry expression and an appropriate number of Sry-expressing cells in the genital ridge are crucial for maintenance of the high level of Sox9 expression to promote testicular differentiation.

During the past few decades, we have gained considerable knowledge of the regulatory gene network in testicular differentiation by identification of key factors. However, these findings still cannot fully explain some cases of DSD. It is likely that the sexual fate decision in the developing gonad depends on a complex network of interacting factors. Further comprehensive approaches will be required to elucidate the regulatory gene network that governs testicular differentiation more precisely.

By employing stem cell biology approaches, germ cells (PGCLCs) have been derived from ESCs and iPS cells, and supporting cells in male gonads (ieSCs) have been generated by direct reprogramming. Induction of other cell lineages including supporting cells in female gonads will be helpful to further elucidate the functional interaction between somatic cells and germ cells in gonads. Such induced cells may be useful materials not only to perform biochemical studies, but also to establish in vitro gametogenesis systems for both sexes. Furthermore, a combination of cell-based analyses of these induced cells and genetic studies in mouse models will significantly contribute to understanding the causes of unexplained DSD in human patients.

Acknowledgments We thank Yuka Fujimoto for her contributions to the analysis of the Sixl and Six4 double-mutant mouse embryo. This work was supported in part by Grants-in-Aid for scientific research from the Ministry of Education, Science, Sports and Culture of Japan, the Japan Society for Promotion of Science, and the Takeda Science Foundation.

Open Access This article is distributed under the terms of the Creative Commons Attribution License which permits any use, distribution, and reproduction in any medium, provided the original author(s) and the source are credited.

\section{Box 1}

Genes involved in genital ridge formation

Nr5al

Orphan nuclear receptor adrenal 4-binding protein $(A d 4 B P)$ [also known as nuclear receptor subfamily 5 , group A, member $1(\mathrm{Nr} 5 \mathrm{al})$ and steroidogenic factor 1 $(S f 1)]$ was first identified as a gene encoding a common transactivating factor that binds to the promoter region of steroid hydroxylase genes [52-54]. In mice, inactivation of $\mathrm{Nr} 5 \mathrm{al}\left(\mathrm{Nr}^{2} \mathrm{al}^{-/-}\right)$leads to complete agenesis of the gonad and adrenal gland [48-50], whereas human NR5Al inactivation results in decompensating primary adrenal failure and small intra-abdominal gonads [185].

Wt1

The gene encoding the zinc finger transcription factor Wilms' tumor $1(W t 1)$ was first identified as the responsible gene for Wilms' tumors. In human patients, mutations of WTI cause a form of kidney cancer primarily in children [186]. Wt1 has two isoforms with or without an additional three amino acids (lysine, threonine, and serine) between the third and fourth zinc finger $(+$ KTS and - KTS, respectively). These two isoforms play distinct roles during embryogenesis. Wt $1-K T S$ is essential for the formation and development of the bipotential gonad [32].

$\operatorname{Lh} x 9$

LIM homeobox 9 (Lhx9) is a member of the LIM homeobox protein family. Inactivation of $L h x 9$ results in regression of the gonads by E13.5 due to markedly reduced cell proliferation in the bipotential gonads [30].

Emx2

Empty spiracles homeobox $2(E m x 2)$ is a homolog of the Drosophila head gap gene empty spiracles (ems). Mouse embryos lacking $\operatorname{Em} x 2\left(E m x 2^{-\prime-}\right)$ have agenesis of the kidneys, ureters, gonads, and genital tracts, while the adrenal glands and bladder develop normally [187]. In forming $E m x 2^{-/-}$genital ridges, coelomic epithelial cells lose their cellular polarity, which is accompanied by aberrant tight junction assembly. There is also an apparent decrease in the number of migrated $E m \times 2^{-/-}$ coelomic epithelial cells in the mesenchymal compartment, resulting in impaired gonad formation [28]. 


\section{Sixl and Six4}

Sixl and Six4 genes belong to the mammalian homolog of the Drosophila sine oculis homeobox (Six) family, which includes six member genes (Sixl to SixO) in the mouse genome. These genes encode transcriptional factors with characteristic Six- and homeo-domains. Six 1 and Six 4 perform redundant functions in mouse embryogenesis. Sixl and Six4 are located in the same genomic region (within $100 \mathrm{~kb}$ on chromosome 12) and have highly overlapping tissue expression during mouse embryogenesis (for reviews [43, 44]). Six 1 and Six4 bind to a common binding site (MEF3 site) and transactivate genes belonging to the myogenic regulatory factor family [188-190]. Sixl and Six4 double-mutant $\left(\right.$ Six $1^{-/-} ;$Six $\left.^{-/-}\right)$mouse embryos are phenotypically different from Sixl ${ }^{-/-}$to Six4 ${ }^{-/-}$single-mutant mouse embryos, indicating redundant functions of Six 1 and Six 4 in mouse embryonic development. For example, loss of both Sixl and Six4, but not alone, leads to a reduction of gonadal size in both sexes and impaired testicular differentiation in $\mathrm{XY}$ gonads. Our previous study further demonstrated that Six 1 and Six 4 play an essential role in size determination of the mouse gonad by regulating the initial growth of gonadal precursor cells before the onset of Sry expression [42].

\section{Gata4}

GATA-binding protein 4 (Gata4) is a member of the GATA zinc finger transcription factor family. Mouse embryos with conventional inactivation of Gata4 $\left(\right.$ Gata $\left.^{-/-}\right)$die before the genital ridge forms [191, 192]. Mouse embryos that are conditionally deficient for Gata4 after E8.75 show no signs of the initiation of genital ridge formation, because their coelomic epithelium remains as a morphologically undifferentiated monolayer [34]. In XY mouse embryos that are homozygous for a Gata4 knock-in allele $\left(\right.$ Gata $\left.^{k i}\right)$, which abrogates Gata4 binding to the cofactor Fog2 (also known as Zfpm2), the genital ridges form but further differentiation into testes is blocked [98].

Podl

Embryos lacking the basic helix-loop-helix transcription factor Podl (Podl lacZlacZ) (also known as Tcf21/ bHLHa23/capsulin/epicardin) show hypoplastic development in both $\mathrm{XX}$ and $\mathrm{XY}$ gonads [40]. Impaired growth begins at E11.5 in both $\mathrm{XX}$ and $\mathrm{XY}$ genital ridges with slight shortening of their length and an irregular surface. Podl lacZ/lacZ gonads further show defects in the formation of testis cords and testis-specific coelomic blood vessels, and a remarkable increase in the number of presumptive fetal Leydig cells that express the cholesterol side-chain cleavage enzyme [40].

$C b x 2$

In addition to the transcriptional factors, the chromatin modification and remodeling factor M33 (also known as Cbx2) is involved in the formation and development of the genital ridges. In genital ridges lacking $C b x 2$ $\left(C b x 2^{-/-}\right)$, the proliferation and ingression of coelomic epithelial cells are likely to be normal, but the gonadal cells show defective proliferation at later stages $[35,36]$.

\section{Insulin/IGF signaling pathway}

Constitutive ablation of the insulin/insulin-like growth factor (IGF) signaling pathway also leads to impaired gonadal development. Mouse embryos lacking the insulin receptor (Insr) and IGF receptor 1(Igflr) exhibit reduced proliferation rates of somatic progenitor cells in both $\mathrm{XX}$ and $\mathrm{XY}$ gonads prior to sex determination together with complete agenesis of the adrenal gland and the absence of testis development [38, 39]. Ablation of insulin/IGF signaling activity also leads to the male-tofemale sex reversal accompanied by reduced Sry expression. However, it is thought that reduced Sry expression could be a secondary effect of the general proliferation defect and subsequent reduction of Sryexpressing pre-Sertoli cells, rather than its direct effect on the regulation of Sry expression.

\section{Box 2}

Genes involved in Sry expression

Wt1

The Wt1-KTS isoform binds to the $S R Y$ promoter region and transactivates SRY expression in vitro [93]. In addition, Wt1-KTS binds to the $\mathrm{Nr} 5 \mathrm{al}$ promoter sequence [33]. Specific abolition of Wt1-KTS in mouse embryos results in smaller gonad formation because of increased apoptosis. However, testicular differentiation markers such as Sox9 and MIS are detected in a small cluster of cells [32]. On the other hand, abolition of the $W t 1+K T S$ isoform results in reduced Sry levels and a sex-reversal phenotype [32], although Wt1+KTS does not transactivate the Sry promoter in vitro [93, 96]. $\mathrm{Wt} 1+\mathrm{KTS}$ is reported to function at the post- 
transcriptional level to regulate RNA expression and to promote translation of an unspliced RNA [97]. Then $\mathrm{Wt} 1+\mathrm{KTS}$ is considered to be implicated in the posttranscriptional regulation of Sry mRNA in testis determination. Abolition of the $W t 1+K T S$ isoform also results in a decrease in cell proliferation of Sryexpressing cells in the coelomic epithelium, which is rescued by the addition of exogenous FGF9 to the cultured gonad [112]. In addition, we previously reported that stable trasfection of Sry into XX embryonic stem cells (ESCs), but not into gonadal somatic cell line cells (i.e., M15 and TM-4 cells), results in the upregulation of Wt1 [193].

\section{Nr5al}

NR5A1 haploinsufficiency in humans causes a male-tofemale sex-reversal phenotype [185, 194-197]. An effect of $\mathrm{Nr} 5 \mathrm{al}$ haploinsufficiency on testicular differentiation is found in $N r 5 a 1^{+/-}$B6 XY $\mathrm{XKR}^{\mathrm{AKR}}$ mice [198], but usually leads to normal testis development in mice. In $\mathrm{Nr}_{5} \mathrm{al}^{-1-}$ mouse embryos, both $\mathrm{XX}$ and $\mathrm{XY}$ gonads regress by E12.5 [48-50]. Because no Sry expression is observed in $\mathrm{Nr}_{5} \mathrm{al}^{-/-}$gonads, it has been proposed that Nr5a1 may be one of the upstream regulators of Sry (for a review, [24] ).

\section{Fog2 and Gata4}

Embryos lacking Friend of GATA-2 (Fog2, also known as zinc finger protein, multitype 2, Zfpm2) show reduced Sry expression and a sex-reversal phenotype [98]. Conventional inactivation of Gata4 in mouse embryos causes embryonic death at around E7.0-E9.5 due to abnormalities in ventral morphogenesis and heart tube formation before genital ridge formation [191, 192]. However, mice containing homozygous mutant alleles of $G a t a 4^{k i}$, which abrogate the interaction of Gata4 with Fog, also show reduced Sry expression and a sexreversal phenotype [98]. These findings suggest that the interaction of Gata4 and co-factor Fog2 is critical for Sry activation.

\section{Sixl and Six4}

Previously, we find that Six1 and Six4 play crucial roles in sex determination by upregulating Sry expression. XY Six $1^{-/-} ;$Six $4^{-/-}$gonads fail to upregulate Sry expression and show impaired testicular differentiation. We further identified $F \circ g 2$ as a direct target of Six 1 and Six4, which is considered necessary for upregulation of Sry. Therefore, the Six1/Six4-Fog2 pathway is required for Sry upregulation. In addition, Six $1^{-/-} ; \operatorname{Six} 4^{-/-}$genital ridges show few Sry-expressing cells in the coelomic epithelium region [42]. This observation suggests that migration of gonadal progenitor cells through the basement membrane layer is unlikely to be essential for Sry activation.

\section{Map3k4}

The boygirl (byg) mutation, which causes XY gonadal sex reversal, is an $\mathrm{A}$ to $\mathrm{T}$ transversion that introduces a premature stop codon in the gene encoding mitogenactivated protein kinase (Mapk) kinase kinase Map3k4 (also known as Mekk4) [99]. E11.5 byg/byg gonads show a growth deficit and dramatic reduction of Sry. MKK4, a direct target of MAP3K4 and p38 MAPK, is activated in the coelomic region of the E11.5 XY wildtype gonad, suggesting that MAPK signaling may be involved in gonadal somatic cell growth and regulation of Sry expression [99].

\section{Gadd $45 g$}

Mice lacking Gadd45g (Gadd45g $g^{-/-}$), which was identified as a gene upregulated by agents that cause DNA damage, also show XY gonadal sex reversal caused by disruption of Sry expression [101, 102]. Gadd45g and Map3k4 genetically interact during sex determination, and transgenic overexpression of Map3k4 rescues gonadal defects in Gadd45 ${ }^{-/-}$ embryos. Sry expression is delayed and reduced in

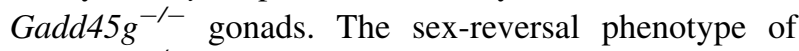

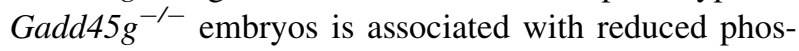
phorylation of p38 MAPK and Gata4 [101, 102].

\section{$C b x 2$}

Mutations of the polycomb group gene $C b x 2$ cause XY sex reversal in both mice and humans [35, 199]. $C b \times 2^{-1-}$ mouse embryos show reduced Sry expression, and growth defects are observed in the genital ridge as soon as Sry expression begins [35]. Either Sry or Sox9 transgenes can rescue the impaired testicular differentiation in $C b x 2^{-/-}$mouse embryos [36]. Direct binding of $\mathrm{Cdx} 2$ to the Nr5al locus shown by ChIP assays and reduced $\mathrm{Nr} 5 a \mathrm{l}$ expression in $\mathrm{Cbx} 2^{-/-}$gonads suggest that $\mathrm{Cbx} 2$ regulates $N r 5 a 1$ expression [37]. However, a genetic interaction between $C b x 2$ and Sry is unclear.

\section{Jmjdla}

Kuroki et al. [104] reported male-to-female sex reversal in mice lacking the H3K9 demethylase Jmjdla (also 
known as $T s g a / J h d m 2 a / K d m 3 a)\left(J m j d l a^{-/-}\right)$, which is accompanied by reduced expression of Sry. Jmjdla ${ }^{-/-}$ mice show abnormal sex differentiation depending on the genetic background. Jmjd1a is expressed in gonadal somatic and germ cells, but not in mesonephric cells at E11.5. Jmjdla has the highest expression level among genes encoding enzymes involved in the maintenance of H3K9 methylation in E11.5 gonadal somatic cells. Jmjdla expression increases from E10.5 and reaches a peak at around E11.5. ChIP assays using purified Nr5a1positive gonadal somatic cells from E11.5 gonads show that Jmjd1a directly binds to regulatory regions within the Sry locus. Furthermore, inactivation of Jmjdla leads to a significant increase in $\mathrm{H} 3 \mathrm{~K} 9 \mathrm{me} 2$ levels within the Sry locus without changing histone $\mathrm{H} 3$ occupancy and H3K9me2 levels of the Sox9 locus [104].

\section{References}

1. Anderson R, Copeland TK, Scholer H, Heasman J, Wylie C (2000) The onset of germ cell migration in the mouse embryo. Mech Dev 91:61-68

2. Ginsburg M, Snow MH, McLaren A (1990) Primordial germ cells in the mouse embryo during gastrulation. Development 110:521-528

3. Hara K, Kanai-Azuma M, Uemura M, Shitara H, Taya C et al (2009) Evidence for crucial role of hindgut expansion in directing proper migration of primordial germ cells in mouse early embryogenesis. Dev Biol 330:427-439

4. Lawson KA, Hage WJ (1994) Clonal analysis of the origin of primordial germ cells in the mouse. Ciba Found Symp 182:68-84 (discussion 84-91)

5. Molyneaux KA, Stallock J, Schaible K, Wylie C (2001) Timelapse analysis of living mouse germ cell migration. Dev Biol 240:488-498

6. Ohinata Y, Payer B, O'Carroll D, Ancelin K, Ono Y et al (2005) Blimp1 is a critical determinant of the germ cell lineage in mice. Nature 436:207-213

7. Saitou M, Barton SC, Surani MA (2002) A molecular programme for the specification of germ cell fate in mice. Nature 418:293-300

8. Tam PP, Snow MH (1981) Proliferation and migration of primordial germ cells during compensatory growth in mouse embryos. J Embryol Exp Morphol 64:133-147

9. Tanaka SS, Matsui Y (2002) Developmentally regulated expression of mil-1 and mil-2, mouse interferon-induced transmembrane protein like genes, during formation and differentiation of primordial germ cells. Mech Dev 119(Suppl 1):S261-S267

10. Tanaka SS, Nagamatsu G, Tokitake Y, Kasa M, Tam PP et al (2004) Regulation of expression of mouse interferon-induced transmembrane protein like gene-3, Ifitm3 (mil-1, fragilis), in germ cells. Dev Dyn 230:651-659

11. Tanaka SS, Yamaguchi YL, Tsoi B, Lickert H, Tam PP (2005) IFITM/Mil/fragilis family proteins IFITM1 and IFITM3 play distinct roles in mouse primordial germ cell homing and repulsion. Dev Cell 9:745-756
12. Gubbay J, Collignon J, Koopman P, Capel B, Economou A et al (1990) A gene mapping to the sex-determining region of the mouse $\mathrm{Y}$ chromosome is a member of a novel family of embryonically expressed genes. Nature 346:245-250

13. Koopman P, Gubbay J, Vivian N, Goodfellow P, Lovell-Badge R (1991) Male development of chromosomally female mice transgenic for Sry. Nature 351:117-121

14. Sinclair AH, Berta P, Palmer MS, Hawkins JR, Griffiths BL et al (1990) A gene from the human sex-determining region encodes a protein with homology to a conserved DNA-binding motif. Nature 346:240-244

15. Just W, Rau W, Vogel W, Akhverdian M, Fredga K et al (1995) Absence of Sry in species of the vole Ellobius. Nat Genet 11:117-118

16. Hughes IA, Houk C, Ahmed SF, Lee PA (2006) Consensus statement on management of intersex disorders. J Pediatr Urol 2:148-162

17. Ono M, Harley VR (2013) Disorders of sex development: new genes, new concepts. Nat Rev Endocrinol 9:79-91

18. Blackless M, Charuvastra A, Derryck A, Fausto-Sterling A, Lauzanne $\mathrm{K}$ et al (2000) How sexually dimorphic are we? Review and synthesis. Am J Hum Biol 12:151-166

19. Brennan J, Capel B (2004) One tissue, two fates: molecular genetic events that underlie testis versus ovary development. Nat Rev Genet 5:509-521

20. Cederroth CR, Pitetti JL, Papaioannou MD, Nef S (2007) Genetic programs that regulate testicular and ovarian development. Mol Cell Endocrinol 265:3-9

21. Eggers S, Sinclair A (2012) Mammalian sex determinationinsights from humans and mice. Chromosome Res 20:215-238

22. Harikae K, Miura K, Kanai Y (2013) Early gonadogenesis in mammals: significance of long and narrow gonadal structure. Dev Dyn 242:330-338

23. Polanco JC, Koopman P (2007) Sry and the hesitant beginnings of male development. Dev Biol 302:13-24

24. Sekido R, Lovell-Badge R (2013) Genetic control of testis development. Sex Dev 7:21-32

25. Ungewitter EK, Yao HH (2013) How to make a gonad: cellular mechanisms governing formation of the testes and ovaries. Sex Dev 7:7-20

26. Wilhelm D, Koopman P (2006) The makings of maleness: towards an integrated view of male sexual development. Nat Rev Genet 7:620-631

27. Karl J, Capel B (1998) Sertoli cells of the mouse testis originate from the coelomic epithelium. Dev Biol 203:323-333

28. Kusaka M, Katoh-Fukui Y, Ogawa H, Miyabayashi K, Baba T et al (2010) Abnormal epithelial cell polarity and ectopic epidermal growth factor receptor (EGFR) expression induced in Emx2 KO embryonic gonads. Endocrinology 151:5893-5904

29. Schmahl J, Eicher EM, Washburn LL, Capel B (2000) Sry induces cell proliferation in the mouse gonad. Development 127:65-73

30. Birk OS, Casiano DE, Wassif CA, Cogliati T, Zhao L et al (2000) The LIM homeobox gene Lhx9 is essential for mouse gonad formation. Nature 403:909-913

31. Kreidberg JA, Sariola H, Loring JM, Maeda M, Pelletier J et al (1993) WT-1 is required for early kidney development. Cell 74:679-691

32. Hammes A, Guo JK, Lutsch G, Leheste JR, Landrock D et al (2001) Two splice variants of the Wilms' tumor 1 gene have distinct functions during sex determination and nephron formation. Cell 106:319-329

33. Wilhelm D, Englert C (2002) The Wilms tumor suppressor WT1 regulates early gonad development by activation of Sf1. Genes Dev 16:1839-1851 
34. Hu YC, Okumura LM, Page DC (2013) Gata4 is required for formation of the genital ridge in mice. PLoS Genet 9:e1003629

35. Katoh-Fukui Y, Tsuchiya R, Shiroishi T, Nakahara Y, Hashimoto $\mathrm{N}$ et al (1998) Male-to-female sex reversal in M33 mutant mice. Nature 393:688-692

36. Katoh-Fukui Y, Miyabayashi K, Komatsu T, Owaki A, Baba T et al (2012) Cbx2, a polycomb group gene, is required for Sry gene expression in mice. Endocrinology 153:913-924

37. Katoh-Fukui Y, Owaki A, Toyama Y, Kusaka M, Shinohara Y et al (2005) Mouse Polycomb M33 is required for splenic vascular and adrenal gland formation through regulating Ad4BP/ SF1 expression. Blood 106:1612-1620

38. Nef S, Verma-Kurvari S, Merenmies J, Vassalli JD, Efstratiadis A et al (2003) Testis determination requires insulin receptor family function in mice. Nature 426:291-295

39. Pitetti JL, Calvel P, Romero Y, Conne B, Truong V et al (2013) Insulin and IGF1 receptors are essential for XX and XY gonadal differentiation and adrenal development in mice. PLoS Genet 9:e1003160

40. Cui S, Ross A, Stallings N, Parker KL, Capel B et al (2004) Disrupted gonadogenesis and male-to-female sex reversal in Pod1 knockout mice. Development 131:4095-4105

41. Tamura M, Kanno Y, Chuma S, Saito T, Nakatsuji N (2001) Pod-1/Capsulin shows a sex- and stage-dependent expression pattern in the mouse gonad development and represses expression of Ad4BP/SF-1. Mech Dev 102:135-144

42. Fujimoto Y, Tanaka SS, Yamaguchi YL, Kobayashi H, Kuroki S et al (2013) Homeoproteins Six1 and Six4 regulate male sex determination and mouse gonadal development. Dev Cell 26:416-430

43. Kawakami K, Sato S, Ozaki H, Ikeda K (2000) Six family genes-structure and function as transcription factors and their roles in development. BioEssays 22:616-626

44. Kumar JP (2009) The sine oculis homeobox (SIX) family of transcription factors as regulators of development and disease. Cell Mol Life Sci 66:565-583

45. Kobayashi H, Kawakami K, Asashima M, Nishinakamura R (2007) Six1 and Six4 are essential for Gdnf expression in the metanephric mesenchyme and ureteric bud formation, while Six 1 deficiency alone causes mesonephric-tubule defects. Mech Dev 124:290-303

46. McCoy EL, Iwanaga R, Jedlicka P, Abbey NS, Chodosh LA et al (2009) Six 1 expands the mouse mammary epithelial stem/ progenitor cell pool and induces mammary tumors that undergo epithelial-mesenchymal transition. J Clin Invest 119:2663-2677

47. Bland ML, Fowkes RC, Ingraham HA (2004) Differential requirement for steroidogenic factor-1 gene dosage in adrenal development versus endocrine function. Mol Endocrinol 18:941-952

48. Luo X, Ikeda Y, Parker KL (1994) A cell-specific nuclear receptor is essential for adrenal and gonadal development and sexual differentiation. Cell 77:481-490

49. Sadovsky Y, Crawford PA, Woodson KG, Polish JA, Clements MA et al (1995) Mice deficient in the orphan receptor steroidogenic factor 1 lack adrenal glands and gonads but express P450 side-chain-cleavage enzyme in the placenta and have normal embryonic serum levels of corticosteroids. Proc Natl Acad Sci USA 92:10939-10943

50. Shinoda K, Lei H, Yoshii H, Nomura M, Nagano M et al (1995) Developmental defects of the ventromedial hypothalamic nucleus and pituitary gonadotroph in the Ftz-F1 disrupted mice. Dev Dyn 204:22-29

51. Fatchiyah Zubair M, Shima Y, Oka S, Ishihara S et al (2006) Differential gene dosage effects of Ad4BP/SF-1 on target tissue development. Biochem Biophys Res Commun 341:1036-1045
52. Honda S, Morohashi K, Nomura M, Takeya H, Kitajima M et al (1993) Ad4BP regulating steroidogenic P-450 gene is a member of steroid hormone receptor superfamily. J Biol Chem 268:7494-7502

53. Lala DS, Rice DA, Parker KL (1992) Steroidogenic factor I, a key regulator of steroidogenic enzyme expression, is the mouse homolog of fushi tarazu-factor I. Mol Endocrinol 6:1249-1258

54. Morohashi K, Zanger UM, Honda S, Hara M, Waterman MR et al (1993) Activation of CYP11A and CYP11B gene promoters by the steroidogenic cell-specific transcription factor, Ad4BP. Mol Endocrinol 7:1196-1204

55. Hoivik EA, Lewis AE, Aumo L, Bakke M (2010) Molecular aspects of steroidogenic factor 1 (SF-1). Mol Cell Endocrinol 315:27-39

56. Lin L, Achermann JC (2008) Steroidogenic factor-1 (SF-1, Ad4BP, NR5A1) and disorders of testis development. Sex Dev 2:200-209

57. Efstratiadis A (1998) Genetics of mouse growth. Int J Dev Biol 42:955-976

58. Arango NA, Lovell-Badge R, Behringer RR (1999) Targeted mutagenesis of the endogenous mouse Mis gene promoter: in vivo definition of genetic pathways of vertebrate sexual development. Cell 99:409-419

59. Sekido R, Lovell-Badge R (2008) Sex determination involves synergistic action of SRY and SF1 on a specific Sox9 enhancer. Nature 453:930-934

60. Shima Y, Miyabayashi K, Baba T, Otake H, Katsura Y et al (2012) Identification of an enhancer in the Ad4BP/SF-1 gene specific for fetal Leydig cells. Endocrinology 153:417-425

61. Hatano O, Takakusu A, Nomura M, Morohashi K (1996) Identical origin of adrenal cortex and gonad revealed by expression profiles of Ad4BP/SF-1. Genes Cells 1:663-671

62. Albrecht KH, Eicher EM (2001) Evidence that Sry is expressed in pre-Sertoli cells and Sertoli and granulosa cells have a common precursor. Dev Biol 240:92-107

63. Bullejos M, Koopman P (2001) Spatially dynamic expression of Sry in mouse genital ridges. Dev Dyn 221:201-205

64. Hacker A, Capel B, Goodfellow P, Lovell-Badge R (1995) Expression of Sry, the mouse sex determining gene. Development 121:1603-1614

65. Jeske YW, Bowles J, Greenfield A, Koopman P (1995) Expression of a linear Sry transcript in the mouse genital ridge. Nat Genet 10:480-482

66. Kidokoro T, Matoba S, Hiramatsu R, Fujisawa M, KanaiAzuma $M$ et al (2005) Influence on spatiotemporal patterns of a male-specific Sox9 activation by ectopic Sry expression during early phases of testis differentiation in mice. Dev Biol 278:511-525

67. Koopman P, Munsterberg A, Capel B, Vivian N, Lovell-Badge R (1990) Expression of a candidate sex-determining gene during mouse testis differentiation. Nature 348:450-452

68. Sekido R, Bar I, Narvaez V, Penny G, Lovell-Badge R (2004) SOX9 is up-regulated by the transient expression of SRY specifically in Sertoli cell precursors. Dev Biol 274:271-279

69. Wilhelm D, Martinson F, Bradford S, Wilson MJ, Combes AN et al (2005) Sertoli cell differentiation is induced both cellautonomously and through prostaglandin signaling during mammalian sex determination. Dev Biol 287:111-124

70. Bishop CE, Whitworth DJ, Qin Y, Agoulnik AI, Agoulnik IU et al (2000) A transgenic insertion upstream of sox9 is associated with dominant $\mathrm{XX}$ sex reversal in the mouse. Nat Genet 26:490-494

71. Qin Y, Bishop CE (2005) Sox9 is sufficient for functional testis development producing fertile male mice in the absence of Sry. Hum Mol Genet 14:1221-1229 
72. Vidal VP, Chaboissier MC, de Rooij DG, Schedl A (2001) Sox9 induces testis development in XX transgenic mice. Nat Genet 28:216-217

73. Bowles J, Schepers G, Koopman P (2000) Phylogeny of the SOX family of developmental transcription factors based on sequence and structural indicators. Dev Biol 227:239-255

74. Schepers GE, Teasdale RD, Koopman P (2002) Twenty pairs of sox: extent, homology, and nomenclature of the mouse and human sox transcription factor gene families. Dev Cell $3: 167-170$

75. Harley VR, Goodfellow PN (1994) The biochemical role of SRY in sex determination. Mol Reprod Dev 39:184-193

76. Harley VR, Jackson DI, Hextall PJ, Hawkins JR, Berkovitz GD et al (1992) DNA binding activity of recombinant SRY from normal males and XY females. Science 255:453-456

77. Jager RJ, Harley VR, Pfeiffer RA, Goodfellow PN, Scherer G (1992) A familial mutation in the testis-determining gene SRY shared by both sexes. Hum Genet $90: 350-355$

78. Mitchell CL, Harley VR (2002) Biochemical defects in eight SRY missense mutations causing XY gonadal dysgenesis. Mol Genet Metab 77:217-225

79. Pontiggia A, Rimini R, Harley VR, Goodfellow PN, LovellBadge R et al (1994) Sex-reversing mutations affect the architecture of SRY-DNA complexes. EMBO J 13:6115-6124

80. Schmitt-Ney M, Thiele H, Kaltwasser P, Bardoni B, Cisternino $M$ et al (1995) Two novel SRY missense mutations reducing DNA binding identified in XY females and their mosaic fathers. Am J Hum Genet 56:862-869

81. Li B, Phillips NB, Jancso-Radek A, Ittah V, Singh R et al (2006) SRY-directed DNA bending and human sex reversal: reassessment of a clinical mutation uncovers a global coupling between the HMG box and its tail. J Mol Biol 360:310-328

82. Harley VR, Layfield S, Mitchell CL, Forwood JK, John AP et al (2003) Defective importin beta recognition and nuclear import of the sex-determining factor SRY are associated with XY sexreversing mutations. Proc Natl Acad Sci USA 100:7045-7050

83. Li B, Zhang W, Chan G, Jancso-Radek A, Liu S et al (2001) Human sex reversal due to impaired nuclear localization of SRY. A clinical correlation. J Biol Chem 276:46480-46484

84. Bradford ST, Hiramatsu R, Maddugoda MP, Bernard P, Chaboissier MC et al (2009) The cerebellin 4 precursor gene is a direct target of SRY and SOX9 in mice. Biol Reprod 80:1178-1188

85. Bhandari RK, Haque MM, Skinner MK (2012) Global genome analysis of the downstream binding targets of testis determining factor SRY and SOX9. PLoS ONE 7:e43380

86. Bhandari RK, Sadler-Riggleman I, Clement TM, Skinner MK (2011) Basic helix-loop-helix transcription factor TCF21 is a downstream target of the male sex determining gene SRY. PLoS ONE 6:e19935

87. Clement TM, Bhandari RK, Sadler-Riggleman I, Skinner MK (2011) SRY directly regulates the neurotrophin 3 promoter during male sex determination and testis development in rats. Biol Reprod 85:277-284

88. Cupp AS, Uzumcu M, Skinner MK (2003) Chemotactic role of neurotropin 3 in the embryonic testis that facilitates male sex determination. Biol Reprod 68:2033-2037

89. Wei P, Pattarini R, Rong Y, Guo H, Bansal PK et al (2012) The Cbln family of proteins interact with multiple signaling pathways. J Neurochem 121:717-729

90. Foster JW, Dominguez-Steglich MA, Guioli S, Kwok C, Weller PA et al (1994) Campomelic dysplasia and autosomal sex reversal caused by mutations in an SRY-related gene. Nature 372:525-530

91. Wagner T, Wirth J, Meyer J, Zabel B, Held M et al (1994) Autosomal sex reversal and campomelic dysplasia are caused by mutations in and around the SRY-related gene SOX9. Cell 79:1111-1120

92. Desclozeaux M, Poulat F, de Santa Barbara P, Soullier S, Jay P et al (1998) Characterization of two Sp1 binding sites of the human sex determining SRY promoter. Biochim Biophys Acta 1397:247-252

93. Hossain A, Saunders GF (2001) The human sex-determining gene SRY is a direct target of WT1. J Biol Chem 276:16817-16823

94. Miyamoto Y, Taniguchi H, Hamel F, Silversides DW, Viger RS (2008) A GATA4/WT1 cooperation regulates transcription of genes required for mammalian sex determination and differentiation. BMC Mol Biol 9:44

95. Pilon N, Daneau I, Paradis V, Hamel F, Lussier JG et al (2003) Porcine SRY promoter is a target for steroidogenic factor 1. Biol Reprod 68:1098-1106

96. Shimamura R, Fraizer GC, Trapman J, Lau YFC, Saunders GF (1997) The Wilms' tumor gene WT1 can regulate genes involved in sex determination and differentiation: SRY, Mullerian-inhibiting substance, and the androgen receptor. Clin Cancer Res 3:2571-2580

97. Bor YC, Swartz J, Morrison A, Rekosh D, Ladomery M et al (2006) The Wilms' tumor 1 (WT1) gene (+KTS isoform) functions with a CTE to enhance translation from an unspliced RNA with a retained intron. Genes Dev 20:1597-1608

98. Tevosian SG, Albrecht KH, Crispino JD, Fujiwara Y, Eicher EM et al (2002) Gonadal differentiation, sex determination and normal Sry expression in mice require direct interaction between transcription partners GATA4 and FOG2. Development 129:4627-4634

99. Bogani D, Siggers P, Brixey R, Warr N, Beddow S et al (2009) Loss of mitogen-activated protein kinase kinase kinase 4 (MAP3K4) reveals a requirement for MAPK signalling in mouse sex determination. PLoS Biol 7:e1000196

100. Takekawa M, Saito H (1998) A family of stress-inducible GADD45-like proteins mediate activation of the stress-responsive MTK1/MEKK4 MAPKKK. Cell 95:521-530

101. Gierl MS, Gruhn WH, von Seggern A, Maltry N, Niehrs C (2012) GADD45G functions in male sex determination by promoting p38 signaling and Sry expression. Dev Cell 23:1032-1042

102. Warr N, Carre GA, Siggers P, Faleato JV, Brixey R et al (2012) Gadd45gamma and Map3k4 interactions regulate mouse testis determination via p38 MAPK-mediated control of Sry expression. Dev Cell 23:1020-1031

103. Czech DP, Lee J, Correia J, Loke H, Moller EK et al (2014) Transient neuroprotection by SRY upregulation in dopamine cells following injury in males. Endocrinology 155:2602-2612

104. Kuroki S, Matoba S, Akiyoshi M, Matsumura Y, Miyachi H et al (2013) Epigenetic regulation of mouse sex determination by the histone demethylase Jmjd1a. Science 341:1106-1109

105. Eicher EM, Washburn LL, Whitney JB 3rd, Morrow KE (1982) Mus poschiavinus $\mathrm{Y}$ chromosome in the C57BL/6J murine genome causes sex reversal. Science 217:535-537

106. Bullejos M, Koopman P (2005) Delayed Sry and Sox9 expression in developing mouse gonads underlies B6-Y(DOM) sex reversal. Dev Biol 278:473-481

107. Wilhelm D, Washburn LL, Truong V, Fellous M, Eicher EM et al (2009) Antagonism of the testis- and ovary-determining pathways during ovotestis development in mice. Mech Dev 126:324-336

108. Hiramatsu R, Matoba S, Kanai-Azuma M, Tsunekawa N, KatohFukui $Y$ et al (2009) A critical time window of Sry action in gonadal sex determination in mice. Development 136:129-138

109. Schmahl J, Capel B (2003) Cell proliferation is necessary for the determination of male fate in the gonad. Dev Biol 258:264-276 
110. Colvin JS, Green RP, Schmahl J, Capel B, Ornitz DM (2001) Male-to-female sex reversal in mice lacking fibroblast growth factor 9. Cell 104:875-889

111. Schmahl J, Kim Y, Colvin JS, Ornitz DM, Capel B (2004) Fgf9 induces proliferation and nuclear localization of FGFR2 in Sertoli precursors during male sex determination. Development 131:3627-3636

112. Bradford ST, Wilhelm D, Bandiera R, Vidal V, Schedl A et al (2009) A cell-autonomous role for WT1 in regulating Sry in vivo. Hum Mol Genet 18:3429-3438

113. Ludbrook LM, Bernard P, Bagheri-Fam S, Ryan J, Sekido R et al (2012) Excess DAX1 leads to XY ovotesticular disorder of sex development (DSD) in mice by inhibiting steroidogenic factor-1 (SF1) activation of the testis enhancer of SRY-box-9 (Sox9). Endocrinology 153:1948-1958

114. Hoyle C, Narvaez V, Alldus G, Lovell-Badge R, Swain A (2002) Dax 1 expression is dependent on steroidogenic factor 1 in the developing gonad. Mol Endocrinol 16:747-756

115. Pfeifer D, Kist R, Dewar K, Devon K, Lander ES et al (1999) Campomelic dysplasia translocation breakpoints are scattered over $1 \mathrm{Mb}$ proximal to SOX9: evidence for an extended control region. Am J Hum Genet 65:111-124

116. Arboleda VA, Fleming A, Barseghyan H, Delot E, Sinsheimer JS et al (2014) Regulation of sex determination in mice by a non-coding genomic region. Genetics 197:885-897

117. Sutton E, Hughes J, White S, Sekido R, Tan J et al (2011) Identification of SOX3 as an XX male sex reversal gene in mice and humans. J Clin Invest 121:328-341

118. Graves JA (2001) From brain determination to testis determination: evolution of the mammalian sex-determining gene. Reprod Fertil Dev 13:665-672

119. Polanco JC, Wilhelm D, Davidson TL, Knight D, Koopman P (2010) Sox 10 gain-of-function causes XX sex reversal in mice: implications for human 22q-linked disorders of sex development. Hum Mol Genet 19:506-516

120. Schepers G, Wilson M, Wilhelm D, Koopman P (2003) SOX8 is expressed during testis differentiation in mice and synergizes with SF1 to activate the Amh promoter in vitro. J Biol Chem 278:28101-28108

121. Sock E, Schmidt K, Hermanns-Borgmeyer I, Bosl MR, Wegner M (2001) Idiopathic weight reduction in mice deficient in the high-mobility-group transcription factor Sox8. Mol Cell Biol 21:6951-6959

122. Chaboissier MC, Kobayashi A, Vidal VI, Lutzkendorf S, van de Kant HJ et al (2004) Functional analysis of Sox8 and Sox9 during sex determination in the mouse. Development 131:1891-1901

123. Barrionuevo F, Georg I, Scherthan H, Lecureuil C, Guillou F et al (2009) Testis cord differentiation after the sex determination stage is independent of Sox 9 but fails in the combined absence of Sox9 and Sox8. Dev Biol 327:301-312

124. Seeherunvong T, Perera EM, Bao Y, Benke PJ, Benigno A et al (2004) 46, XX sex reversal with partial duplication of chromosome arm 22q. Am J Med Genet A 127A:149-151

125. Aleck KA, Argueso L, Stone J, Hackel JG, Erickson RP (1999) True hermaphroditism with partial duplication of chromosome 22 and without SRY. Am J Med Genet 85:2-4

126. Kim Y, Kobayashi A, Sekido R, DiNapoli L, Brennan J et al (2006) Fgf9 and Wnt4 act as antagonistic signals to regulate mammalian sex determination. PLoS Biol 4:e187

127. Bagheri-Fam S, Sim H, Bernard P, Jayakody I, Taketo MM et al (2008) Loss of Fgfr2 leads to partial XY sex reversal. Dev Biol 314:71-83

128. Kim Y, Bingham N, Sekido R, Parker KL, Lovell-Badge R et al (2007) Fibroblast growth factor receptor 2 regulates proliferation and Sertoli differentiation during male sex determination. Proc Natl Acad Sci USA 104:16558-16563
129. DiNapoli L, Batchvarov J, Capel B (2006) FGF9 promotes survival of germ cells in the fetal testis. Development 133:1519-1527

130. Bowles J, Feng CW, Spiller C, Davidson TL, Jackson A et al (2010) FGF9 suppresses meiosis and promotes male germ cell fate in mice. Dev Cell 19:440-449

131. Malki S, Nef S, Notarnicola C, Thevenet L, Gasca S et al (2005) Prostaglandin D2 induces nuclear import of the sex-determining factor SOX9 via its cAMP-PKA phosphorylation. EMBO J 24:1798-1809

132. Wilhelm D, Hiramatsu R, Mizusaki H, Widjaja L, Combes AN et al (2007) SOX9 regulates prostaglandin D synthase gene transcription in vivo to ensure testis development. J Biol Chem 282:10553-10560

133. Nachtigal MW, Hirokawa Y, Enyeart-VanHouten DL, Flanagan JN, Hammer GD et al (1998) Wilms' tumor 1 and Dax-1 modulate the orphan nuclear receptor SF-1 in sex-specific gene expression. Cell 93:445-454

134. Tremblay JJ, Robert NM, Viger RS (2001) Modulation of endogenous GATA-4 activity reveals its dual contribution to Mullerian inhibiting substance gene transcription in Sertoli cells. Mol Endocrinol 15:1636-1650

135. Tremblay JJ, Viger RS (2001) Nuclear receptor Dax-1 represses the transcriptional cooperation between GATA- 4 and SF-1 in Sertoli cells. Biol Reprod 64:1191-1199

136. Barrionuevo F, Bagheri-Fam S, Klattig J, Kist R, Taketo MM et al (2006) Homozygous inactivation of Sox9 causes complete XY sex reversal in mice. Biol Reprod 74:195-201

137. Chassot AA, Ranc F, Gregoire EP, Roepers-Gajadien HL, Taketo MM et al (2008) Activation of beta-catenin signaling by Rspo1 controls differentiation of the mammalian ovary. Hum Mol Genet 17:1264-1277

138. Maatouk DM, DiNapoli L, Alvers A, Parker KL, Taketo MM et al (2008) Stabilization of beta-catenin in XY gonads causes male-to-female sex-reversal. Hum Mol Genet 17:2949-2955

139. Tomizuka K, Horikoshi K, Kitada R, Sugawara Y, Iba Y et al (2008) R-spondin1 plays an essential role in ovarian development through positively regulating Wnt-4 signaling. Hum Mol Genet 17:1278-1291

140. Bernard P, Ryan J, Sim H, Czech DP, Sinclair AH et al (2012) Wnt signaling in ovarian development inhibits Sf1 activation of Sox9 via the Tesco enhancer. Endocrinology 153:901-912

141. Munger SC, Aylor DL, Syed HA, Magwene PM, Threadgill DW et al (2009) Elucidation of the transcription network governing mammalian sex determination by exploiting strain-specific susceptibility to sex reversal. Genes Dev 23:2521-2536

142. Munger SC, Natarajan A, Looger LL, Ohler U, Capel B (2013) Fine time course expression analysis identifies cascades of activation and repression and maps a putative regulator of mammalian sex determination. PLoS Genet 9:e1003630

143. Kashimada K, Svingen T, Feng CW, Pelosi E, Bagheri-Fam S et al (2011) Antagonistic regulation of Cyp26b1 by transcription factors SOX9/SF1 and FOXL2 during gonadal development in mice. FASEB J 25:3561-3569

144. Bowles J, Knight D, Smith C, Wilhelm D, Richman J et al (2006) Retinoid signaling determines germ cell fate in mice. Science 312:596-600

145. Koubova J, Menke DB, Zhou Q, Capel B, Griswold MD et al (2006) Retinoic acid regulates sex-specific timing of meiotic initiation in mice. Proc Natl Acad Sci USA 103:2474-2479

146. Mork L, Maatouk DM, McMahon JA, Guo JJ, Zhang P et al (2012) Temporal differences in granulosa cell specification in the ovary reflect distinct follicle fates in mice. Biol Reprod 86:37

147. Merchant-Larios H, Centeno B (1981) Morphogenesis of the ovary from the sterile $\mathrm{W} / \mathrm{Wv}$ mouse. Prog Clin Biol Res 59B:383-392 
148. Behringer RR, Cate RL, Froelick GJ, Palmiter RD, Brinster RL (1990) Abnormal sexual development in transgenic mice chronically expressing mullerian inhibiting substance. Nature 345:167-170

149. Schmidt D, Ovitt CE, Anlag K, Fehsenfeld S, Gredsted L et al (2004) The murine winged-helix transcription factor Foxl2 is required for granulosa cell differentiation and ovary maintenance. Development 131:933-942

150. DeFalco T, Takahashi S, Capel B (2011) Two distinct origins for Leydig cell progenitors in the fetal testis. Dev Biol 352:14-26

151. Yao HH, Whoriskey W, Capel B (2002) Desert Hedgehog/Patched 1 signaling specifies fetal Leydig cell fate in testis organogenesis. Genes Dev 16:1433-1440

152. Brennan J, Tilmann C, Capel B (2003) Pdgfr-alpha mediates testis cord organization and fetal Leydig cell development in the XY gonad. Genes Dev 17:800-810

153. Gnessi L, Basciani S, Mariani S, Arizzi M, Spera G et al (2000) Leydig cell loss and spermatogenic arrest in platelet-derived growth factor (PDGF)-A-deficient mice. J Cell Biol 149:1019-1026

154. Kitamura K, Yanazawa M, Sugiyama N, Miura H, Iizuka-Kogo A et al (2002) Mutation of ARX causes abnormal development of forebrain and testes in mice and X-linked lissencephaly with abnormal genitalia in humans. Nat Genet 32:359-369

155. Bagheri-Fam S, Argentaro A, Svingen T, Combes AN, Sinclair AH et al (2011) Defective survival of proliferating Sertoli cells and androgen receptor function in a mouse model of the ATR-X syndrome. Hum Mol Genet 20:2213-2224

156. Archambeault DR, Yao HH (2010) Activin A, a product of fetal Leydig cells, is a unique paracrine regulator of Sertoli cell proliferation and fetal testis cord expansion. Proc Natl Acad Sci USA 107:10526-10531

157. Edson MA, Nagaraja AK, Matzuk MM (2009) The mammalian ovary from genesis to revelation. Endocr Rev 30:624-712

158. Martineau J, Nordqvist K, Tilmann C, Lovell-Badge R, Capel B (1997) Male-specific cell migration into the developing gonad. Curr Biol 7:958-968

159. Combes AN, Wilhelm D, Davidson T, Dejana E, Harley V et al (2009) Endothelial cell migration directs testis cord formation. Dev Biol 326:112-120

160. Cool J, Carmona FD, Szucsik JC, Capel B (2008) Peritubular myoid cells are not the migrating population required for testis cord formation in the XY gonad. Sex Dev 2:128-133

161. Kanai Y, Kanai-Azuma M, Tajima Y, Birk OS, Hayashi Y et al (2000) Identification of a stromal cell type characterized by the secretion of a soluble integrin-binding protein, MFG-E8, in mouse early gonadogenesis. Mech Dev 96:223-227

162. Gill ME, Hu YC, Lin Y, Page DC (2011) Licensing of gametogenesis, dependent on RNA binding protein DAZL, as a gateway to sexual differentiation of fetal germ cells. Proc Natl Acad Sci USA 108:7443-7448

163. Lin Y, Gill ME, Koubova J, Page DC (2008) Germ cell-intrinsic and -extrinsic factors govern meiotic initiation in mouse embryos. Science 322:1685-1687

164. Ruggiu M, Speed R, Taggart M, McKay SJ, Kilanowski F et al (1997) The mouse Dazla gene encodes a cytoplasmic protein essential for gametogenesis. Nature 389:73-77

165. Saunders PT, Turner JM, Ruggiu M, Taggart M, Burgoyne PS et al (2003) Absence of mDazl produces a final block on germ cell development at meiosis. Reproduction 126:589-597

166. Schrans-Stassen BH, Saunders PT, Cooke HJ, de Rooij DG (2001) Nature of the spermatogenic arrest in Dazl ${ }^{-/-}$mice. Biol Reprod 65:771-776

167. Seligman J, Page DC (1998) The Dazh gene is expressed in male and female embryonic gonads before germ cell sex differentiation. Biochem Biophys Res Commun 245:878-882
168. Tanaka SS, Toyooka Y, Akasu R, Katoh-Fukui Y, Nakahara Y et al (2000) The mouse homolog of Drosophila Vasa is required for the development of male germ cells. Genes Dev 14:841-853

169. Toyooka Y, Tsunekawa N, Takahashi Y, Matsui Y, Satoh M et al (2000) Expression and intracellular localization of mouse Vasa-homologue protein during germ cell development. Mech Dev 93:139-149

170. Seisenberger S, Andrews S, Krueger F, Arand J, Walter J et al (2012) The dynamics of genome-wide DNA methylation reprogramming in mouse primordial germ cells. Mol Cell 48:849-862

171. Hayashi K, Ogushi S, Kurimoto K, Shimamoto S, Ohta H et al (2012) Offspring from oocytes derived from in vitro primordial germ cell-like cells in mice. Science 338:971-975

172. Hayashi K, Ohta H, Kurimoto K, Aramaki S, Saitou M (2011) Reconstitution of the mouse germ cell specification pathway in culture by pluripotent stem cells. Cell 146:519-532

173. Hayashi K, Surani MA (2009) Self-renewing epiblast stem cells exhibit continual delineation of germ cells with epigenetic reprogramming in vitro. Development 136:3549-3556

174. Buganim Y, Itskovich $\mathrm{E}$, Hu YC, Cheng AW, Ganz K et al (2012) Direct reprogramming of fibroblasts into embryonic Sertoli-like cells by defined factors. Cell Stem Cell 11:373-386

175. Sato T, Katagiri K, Gohbara A, Inoue K, Ogonuki N et al (2011) In vitro production of functional sperm in cultured neonatal mouse testes. Nature 471:504-507

176. Uhlenhaut NH, Jakob S, Anlag K, Eisenberger T, Sekido R et al (2009) Somatic sex reprogramming of adult ovaries to testes by FOXL2 ablation. Cell 139:1130-1142

177. Matson CK, Murphy MW, Sarver AL, Griswold MD, Bardwell VJ et al (2011) DMRT1 prevents female reprogramming in the postnatal mammalian testis. Nature 476:101-104

178. Ottolenghi C, Omari S, Garcia-Ortiz JE, Uda M, Crisponi L et al (2005) Foxl2 is required for commitment to ovary differentiation. Hum Mol Genet 14:2053-2062

179. Ottolenghi C, Pelosi E, Tran J, Colombino M, Douglass E et al (2007) Loss of Wnt 4 and Foxl2 leads to female-to-male sex reversal extending to germ cells. Hum Mol Genet 16:2795-2804

180. Raymond CS, Murphy MW, O'Sullivan MG, Bardwell VJ, Zarkower D (2000) Dmrt1, a gene related to worm and fly sexual regulators, is required for mammalian testis differentiation. Genes Dev 14:2587-2595

181. Cutting A, Chue J, Smith CA (2013) Just how conserved is vertebrate sex determination? Dev Dyn 242:380-387

182. Matsuda M, Nagahama Y, Shinomiya A, Sato T, Matsuda C et al (2002) DMY is a Y-specific DM-domain gene required for male development in the medaka fish. Nature 417:559-563

183. Yoshimoto S, Okada E, Umemoto H, Tamura K, Uno Y et al (2008) A W-linked DM-domain gene, DM-W, participates in primary ovary development in Xenopus laevis. Proc Natl Acad Sci USA 105:2469-2474

184. Yamauchi Y, Riel JM, Stoytcheva Z, Ward MA (2014) Two Y genes can replace the entire $Y$ chromosome for assisted reproduction in the mouse. Science 343:69-72

185. Achermann JC, Ito M, Ito M, Hindmarsh PC, Jameson JL (1999) A mutation in the gene encoding steroidogenic factor- 1 causes $X Y$ sex reversal and adrenal failure in humans. Nat Genet 22:125-126

186. Haber DA, Buckler AJ, Glaser T, Call KM, Pelletier J et al (1990) An internal deletion within an 11p13 zinc finger gene contributes to the development of Wilms' tumor. Cell 61:1257-1269

187. Miyamoto N, Yoshida M, Kuratani S, Matsuo I, Aizawa S (1997) Defects of urogenital development in mice lacking Emx2. Development 124:1653-1664

188. Parmacek MS, Ip HS, Jung F, Shen T, Martin JF et al (1994) A novel myogenic regulatory circuit controls slow/cardiac 
troponin $\mathrm{C}$ gene transcription in skeletal muscle. Mol Cell Biol 14:1870-1885

189. Spitz F, Demignon J, Porteu A, Kahn A, Concordet JP et al (1998) Expression of myogenin during embryogenesis is controlled by Six/sine oculis homeoproteins through a conserved MEF3 binding site. Proc Natl Acad Sci USA 95:14220-14225

190. Giordani J, Bajard L, Demignon J, Daubas P, Buckingham M et al (2007) Six proteins regulate the activation of Myf5 expression in embryonic mouse limbs. Proc Natl Acad Sci USA 104:11310-11315

191. Kuo CT, Morrisey EE, Anandappa R, Sigrist K, Lu MM et al (1997) GATA4 transcription factor is required for ventral morphogenesis and heart tube formation. Genes Dev 11: 1048-1060

192. Molkentin JD, Lin Q, Duncan SA, Olson EN (1997) Requirement of the transcription factor GATA4 for heart tube formation and ventral morphogenesis. Genes Dev 11:1061-1072

193. Toyooka Y, Tanaka SS, Hirota O, Tanaka S, Takagi N et al (1998) Wilms' tumor suppressor gene (WT1) as a target gene of SRY function in a mouse ES cell line transfected with SRY. Int J Dev Biol 42:1143-1151

194. Achermann JC, Ozisik G, Ito M, Orun UA, Harmanci K et al (2002) Gonadal determination and adrenal development are regulated by the orphan nuclear receptor steroidogenic factor-1, in a dose-dependent manner. J Clin Endocrinol Metab 87:1829-1833

195. Biason-Lauber A, Schoenle EJ (2000) Apparently normal ovarian differentiation in a prepubertal girl with transcriptionally inactive steroidogenic factor 1 (NR5A1/SF-1) and adrenocortical insufficiency. Am J Hum Genet 67:1563-1568

196. Lin L, Philibert P, Ferraz-de-Souza B, Kelberman D, Homfray T et al (2007) Heterozygous missense mutations in steroidogenic factor 1 (SF1/Ad4BP, NR5A1) are associated with 46, XY disorders of sex development with normal adrenal function. J Clin Endocrinol Metab 92:991-999

197. Mallet D, Bretones P, Michel-Calemard L, Dijoud F, David M et al (2004) Gonadal dysgenesis without adrenal insufficiency in a 46, XY patient heterozygous for the nonsense C16X mutation: a case of SF1 haploinsufficiency. J Clin Endocrinol Metab 89:4829-4832

198. Correa SM, Washburn LL, Kahlon RS, Musson MC, Bouma GJ et al (2012) Sex reversal in C57BL/6J XY mice caused by increased expression of ovarian genes and insufficient activation of the testis determining pathway. PLoS Genet 8:e1002569

199. Biason-Lauber A, Konrad D, Meyer M, DeBeaufort C, Schoenle EJ (2009) Ovaries and female phenotype in a girl with 46, XY karyotype and mutations in the CBX2 gene. Am J Hum Genet 84:658-663 